\title{
柱列状改良体の連結による 橋台耐震補強工法に関する実験的検討
}

\author{
池本 宏文 1 ・高崎 秀明 2 ・藤原 寅士良 3 ・佐名川 太亮 4 ・西岡 英俊 5
}

1正会員 東日本旅客鉄道株式会社 JR東日本研究開発センター フロンティアサービス研究所

（テ331-8513 埼玉県さいたま市北区日進町2-479）

E-mail: ikemoto@jreast.co.jp

2正会員 東日本旅客鉄道株式会社 JR東日本研究開発センター フロンティアサービス研究所

（テ331-8513 埼玉県さいたま市北区日進町2-479）

E-mail: h-takasaki@jreast.co.jp

3正会員 東日本旅客鉄道株式会社＼cjkstart構造技術センター（†151-8578 東京都渋谷区代々木2-2-6）

E-mail: t-fujiwara@jreast.co.jp

4正会員 公益財団法人鉄道総合技術研究所 構造物技術研究部（干185-8540 東京都国分寺市光町2-8-38）

E-mail: sanagawa.taisuke.39@rtri.or.jp

5 正会員 公益財団法人鉄道総合技術研究所 構造物技術研究部（ $\overline{1} 185-8540$ 東京都国分寺市光町2-8-38）

E-mail: nishioka.hidetoshi.58@ rtri.or.jp

橋台の耐震補強を目的として，背面盛土内に柱列状に地盤改良体（以下，改良体と称する）を造成し， 橋台と改良体を連結して一体化する工法に関して, 補強効果, 補強メカニズムを検証するため, 桁重量が 大きい重力式橋台を想定した重力場での振動台実験を実施した。その結果，橋台，改良体，および改良体 に挟まれた背面盛土が一体となって挙動するため, 橋台背面近傍での盛土の沈下量は小さくなり, 改良体 に生じる水平方向, 鉛直方向の地盤抵抗力が連結材を介して橋台の抵抗力として働くことで, 橋台の安定 性が向上することを確認した。 また，崩壊時は改良体の背面側にすべり面が発生して，その範囲が沈下し， 橋台は滑動モードで崩壊に至ることを確認した.

Key Words: abutment, backfill of abutment, seismic retrofitting, shaking table test, soil-cement column

\section{1. はじめに}

鉄道，および道路の橋台における地震時の被害には，

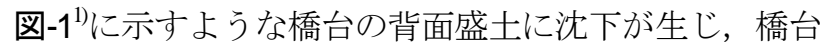
と背面盛土の間に相対変位が生じているものが多数確認 されている例えば鎙道では 1) 4)，道路では 5) 8). 2011 年に発生した 東北地方太平洋沖地震では，鉄道橋台において 104 箇所 の被害が発生し，そのうち，橋台背面盛土の沈下の被害 が 49 箇所（全被害箇所の 47\%）を占めていた。また, 鉄道橋台の被害は軟弱な地盤上に位置する箇所ほど発生 しやすい傾向にあった ${ }^{4)}$ ．道路においては，東北地方整 備局が管理する本線橋, 側道橋の 1572 橋に対して緊急 点検が実施され，960 橋，2192 箇所において被害が確認 された. 被害箇所の中でも橋台背面盛土の沈下の被害数 量が最も多く，649 箇所（全被害箇所の 30\%） で発生 ${ }^{7}$ しており，それが主たる要因となって橋の機能に支障が
生じた事例が多く見られた ${ }^{8)}$.また，液状化の影響によ り，橋台が橋桁側に移動する被害や，河川堤防に大きな 被害が生じた周辺箇所に位置する道路橋において，周辺

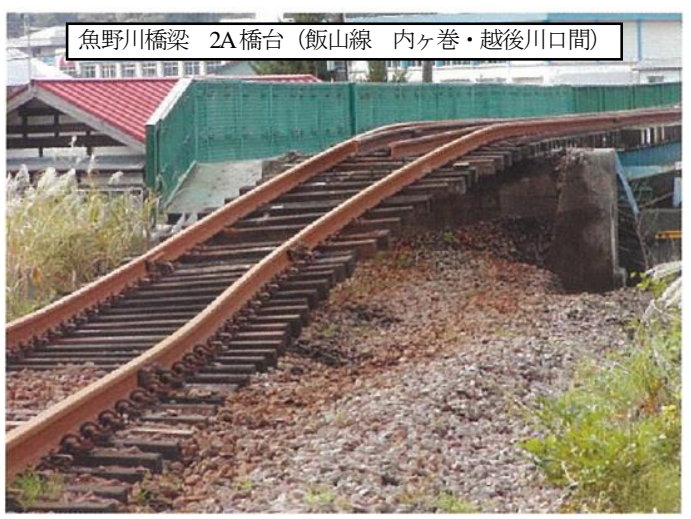

図-1 新潟県中越地震における被災事例 ${ }^{1)}$ 
地盤の沈下による段差が生じた被害も報告されている ${ }^{8)}$. 以上のように東北地方太平洋沖地震では鉄道，および道 路において，橋台の背面盛土の沈下寸る被害が多数確認 されている.

このような橋台背面盛土の沈下の原因は，1)橋台の前 方への変位に伴う背面盛土の落込みによるもの，2)背面 盛土自体の摇すり込み沈下，3)軟弱地盤における地盤と 盛土の振動による土の強度低下，および側方流動による 沈下，4)液状化地盤の側方流動に伴う橋台変位による沈 下などによるもの ${ }^{5), 69,9), 10) ~ と い わ れ て い る . ~}$

鉄道では橋台と背面盛土の間に発生する相対変位が軌 道面に著しい変位を生じさせ，それが列車の走行安全性 の低下につながることとなる. 鉄道は, 盛土，高架橋， トンネル，軌道など様々な構造物が線状に構成されてい るため，ある箇所で軌道に大変位が発生した場合は，そ れが原因となり線区全体の機能不全に直結する恐れがあ る。一方で首都直下地震の近年中の発生が予測されてい る中，鉄道事業者にとって既存構造物の而震補強を行う ことは喫緊の課題となっている.

筆者らは，相対変位の抑制を目的として，背面盛土内 に軌道の脇に沿って柱列状の地盤改良体（以下，改良体 と称する）を造成することで，橋台に作用する土圧を低 減させ，橋台変形に伴う背面盛土の沈下を抑制する而震 補強工法を考案し，実験的に検討を進めてきた ${ }^{11)}$. 既往 の研究では，鉄桁のように桁重量が小さい場合は，桁慣
性力に比して土圧が大きいため，土圧の低減に伴う而震 性の向上効果が大きくなることを確認している. しかし ながら，コンクリート桁のように桁慣性力の割合が大き い場合は，土圧が低減されたとしても，桁重量の小さい ものと比較して，耐震性の向上効果が得られないことが 確認されている ${ }^{12,13)}$. そこで，筆者らは，桁重量が大き い場合における効果的な補強工法の開発を目的として, 橋台背面に造成した改良体と橋台を連結して，一体化を 図ることで而震性を向上させる工法を提案し，実験的に 水平方向の地震動に対する補強効果, 補強メカニズムの 検証を行った．本稿では，縮尺 1/15 の重力式橋台の模 型を用いて重力場での振動台実験を行った内容について 報告する.

\section{2. 橋台の耐震補強工法}

\section{（1）既往の補強工法}

鉄道における而震補強工法には，橋台のフーチング前

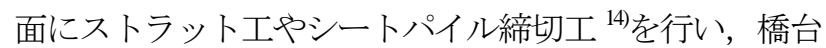
基部の滑動を抑制する工法が行われている．また，近年， ハイスペックネイリング工法を用いて，補強土構造する 工法 ${ }^{15}$ ) 既設の鉄桁，橋台，背面盛土を一体化（既設盛 土一体化橋梁 ${ }^{10}$ ) し，橋台・背面盛土における耐震性の 向上，および橋梁自体の延命化を図る工法が開発され， 適用されている。また，橋台の背面盛土側を補強する工

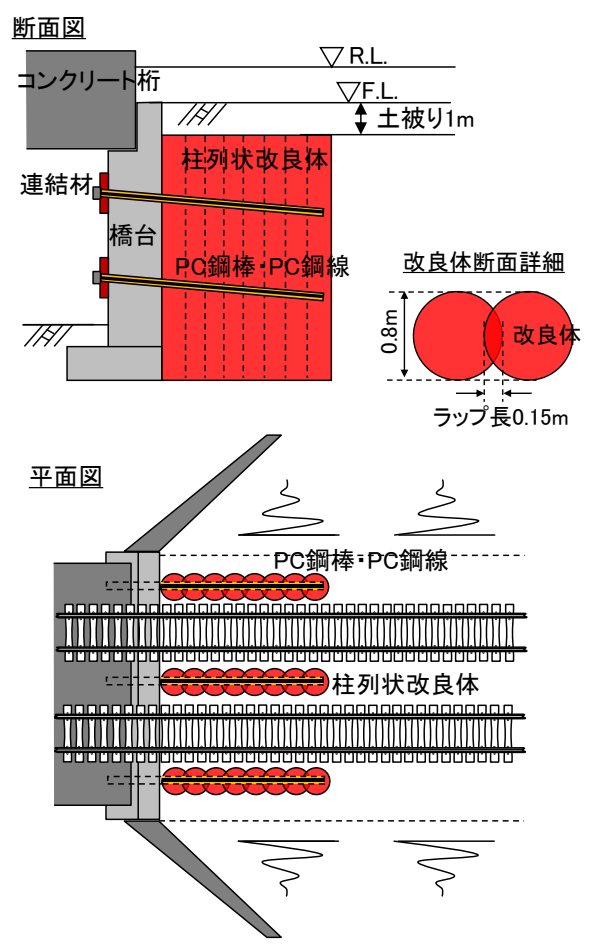

(a) 橋台の前面側から連結する方法

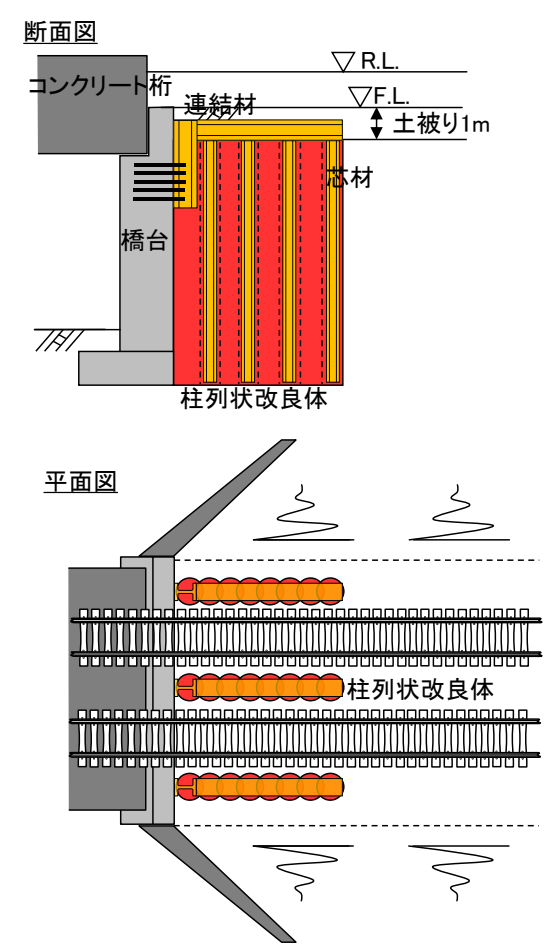

(b) 橋台の背面側から連結する方法

図-2 提案の補強工法 
法として，背面盛土に薬液注入を行い，沈下抑制，およ び盛土自体の強度向上による変形抑制を図る工法 ${ }^{2}$ も行 われている.

道路では，橋台の背面側に踏掛板を設置して，橋台と 背面盛土との相対変位を抑制する対策が行われている ${ }^{17}$ また，橋台，および橋脚を含めた橋梁の全体構造系にお ける而震性能の向上を図る工法として，免震工法，慣性 力分散工法, 変位拘束工法 ${ }^{18)}$ が開発され, 橋台の耐力が 不足する場合にブラケット増設や背面土地盤改良などの 対策が提案されている. また，液状化地盤における橋台 の而震補強工法として, 斜杭や鋼管矢板壁をフーチング 側面において一体化，および鋼管矢板壁をフーチング前 面に施工する補強工法の開発が進められている ${ }^{19}$.

\section{（2）柱列状改良体の連結による補強工法}

提案工法は，図-2 に示すように橋台の背面側から盛 土内にセメント系の材料を用いて, 柱列状の改良体を造 成後, 橋台と改良体を連結して一体化する工法である. 既往の補強工法では，橋台，または背面盛士のいずれか に対して補強を施すものが多いが，提案工法は，背面盛 土の一部を改良しつつ，橋台と改良体を一体化すること で橋台の耐震性を向上させ，背面盛土の沈下抑制を図る ところが特徴である.

改良体の造成は, 架線に支障しない高さの低空頭型機 械を用いて機械攪拌もしくは噴射攪拌により施工する. 改良体は軌道の両端付近に直径 $\phi 800 \mathrm{~mm}$ 程度のものを $150 \mathrm{~mm}$ 程度以上ラップさせながら連続的に施工する. 改良体の土被りは，噴射擋拌工法を用いる場合に $1 \mathrm{~m}$ 程 度確保する必要があるため，それを前提として設定した。 また, 改良体の強度は, 連結材との付着を確保し, 橋台 と改良体を一体の構造とするため, $5 \mathrm{~N} / \mathrm{mm}^{2}$ 程度と設定 した.

橋台と改良体を連結する方法は, 施工環境に応じて, 橋台の前面側と背面側から行う2つの方法を想定してい る. 前面側から施工寸る場合は，小型削孔機械を用いて, 橋台と改良体をコア削孔し，PC 鋼棒や PC 鋼線などを挿 入後, 孔内にグラウトを充填して連結する. また，橋台 の背面側において施工寸る場合は，改良体を造成直後に 改良体内に鉛直方向に $\mathrm{H}$ 形鋼などの芯材を挿入し, 改 良体の天端に連結する部材を設置後, 橋台の背面側から あと施工アンカーを施工して連結を行う。

\section{3. 振動台実験の概要}

\section{(1) 模型および実験ケースの概要}

実験は，表-1 に示寸ような改良体の有無や連結の有 無, および改良体の線路方向の長さを変えた 4 ケースと した. Case1 は無補強のケース, Case2, Case3 は橋台の
高さと等しい長さの改良体を用いて, 橋台と連結しない ケースと連結するケース, Case4 は Case2 の線路方向に 半分の長さの改良体を用いて橋台と連結寸るケースであ る. 橋台模型は首都圈にある高さ $8 \mathrm{~m}$ 程度の重力式橋台 を想定し，縮尺を $1 / 15$ となるように寸法を設定した.

表-2 は実物と模型（Case2，Case3）の寸法関係を示した ものであり, 改良体の間隔は $4.3 \mathrm{~m}$, 改良径は $\phi 0.8 \mathrm{~m}$ 程 度とした．相似則は香川により提案されている $1 \mathrm{G}$ 場に おける相似則 ${ }^{20}$ を用いた. 図-3に模型概要および計測器 配置を示寸. また, 図-4に橋台・改良体模型の状況を 示寸. 模型地盤は気乾状態の東北硅砂 6 号を使用し, 支 持地盤は $D_{\mathrm{r}}=80 \%$, 背面盛土は $D_{\mathrm{r}}=60 \%$ となるように $50 \mathrm{~mm}$ の層厚管理により作製した. 表-3 に模型地盤の物 性值を示寸.

実験には剛土槽（内幅 $2000 \mathrm{~mm} \times$ 内奥行 $1000 \mathrm{~mm} \times$ $1200 \mathrm{~mm}$ ）を用いて, 模型の縮尺, および改良体の間隔 の再現性から奥行き方向に $140 \mathrm{~mm}$ の間隔材を設置して $860 \mathrm{~mm}$ にして使用した. 土槽の 1 側面はアクリル構造 としており, 背面盛土の崩壊形状を観察するため, アク リル面に沿って色砂，および標点（ $\phi 10 \mathrm{~mm} ）$ を設置し た。 また，背面盛土の表面には上載荷重 $0.67 \mathrm{kN} / \mathrm{m}^{2}$ （実 物 $10 \mathrm{kN} / \mathrm{m}^{2}$ ）を袋詰めした鉛玉を設置した.

表-1 実験ケース

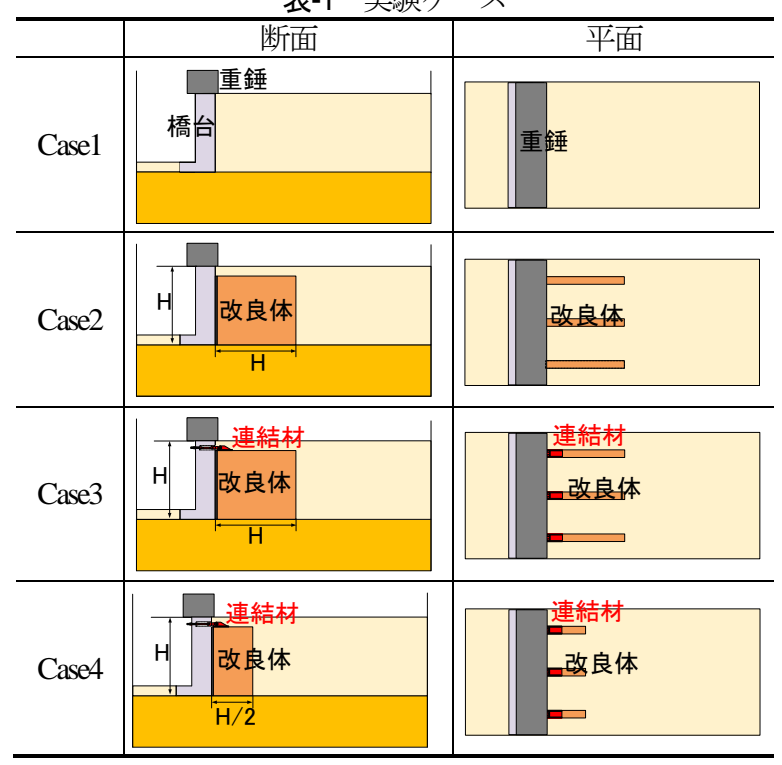

表-2 実物と模型の寸法関係 単位 : m

\begin{tabular}{c|c|c}
\hline & 実物 & 模型 $(\mathrm{Case} \cdot 3)$ \\
\hline 橋台高さ & 8 & 0.535 \\
\hline フーチング幅 & 3.6 & 0.24 \\
\hline フーチング高さ & 1 & 0.067 \\
\hline 改良体長さ & 8 & 0.535 \\
\hline 改良体径 $\phi$ & 0.8 & 0.0515 \\
\hline 改良体間隔 & 4.3 & 0.287 \\
\hline
\end{tabular}




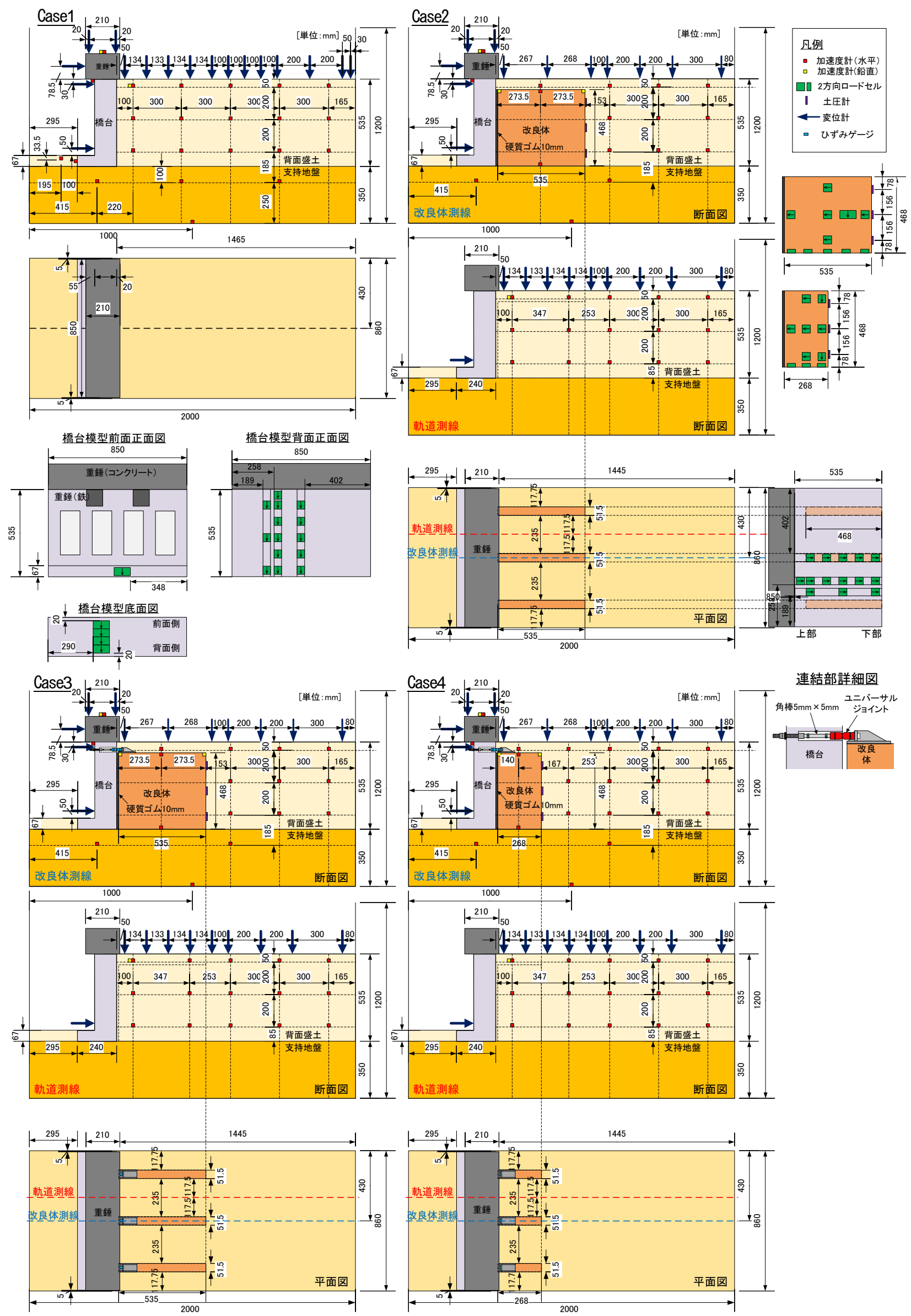

図-3 模型概要・計測器配置図 


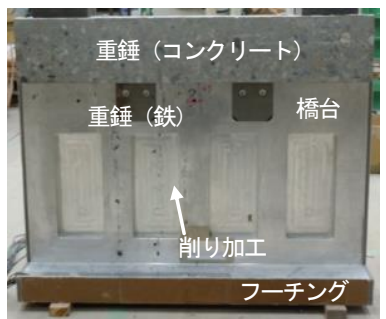

(a) 橋台模型（前面側）

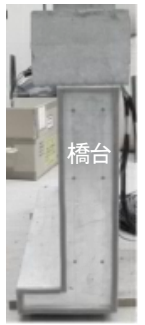

(c) 橋台模型 (側面)

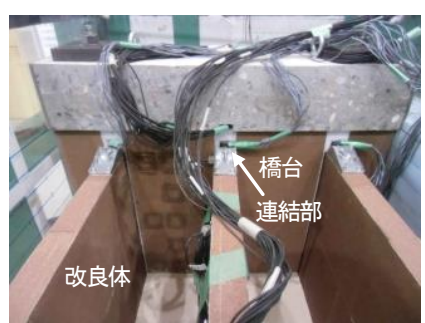

(b) 改良体設置状況（Case3）

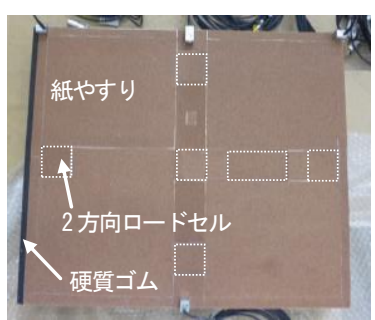

(d) 改良体側面

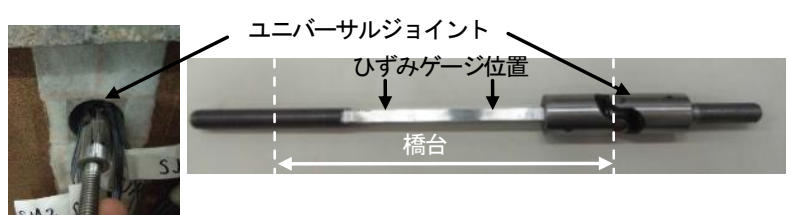

(e) 連結部の詳細構造

図-4 模型の状況写真

表-3 模型地盤の物性值

\begin{tabular}{c|c|c|c|c}
\hline 土層 & $\begin{array}{c}\text { 相対密度 } \\
D_{\mathrm{r}}(\%)\end{array}$ & $\begin{array}{c}\text { 単位体積重量 } \\
\gamma\left(\mathrm{kN} / \mathrm{m}^{3}\right)\end{array}$ & $\begin{array}{c}\text { 内部摩擦角 } \\
\phi_{\text {peak }}\left(\begin{array}{c}\text { 粘着力 } \\
c_{\text {peak }}\left(\mathrm{kN} / \mathrm{m}^{2}\right)\end{array}\right.\end{array}$ \\
\hline 支持地盤 & 80 & 15.9 & 43.8 & 1.4 \\
\hline 背面盛土 & 60 & 15.3 & 39.8 & 1.1 \\
\hline
\end{tabular}

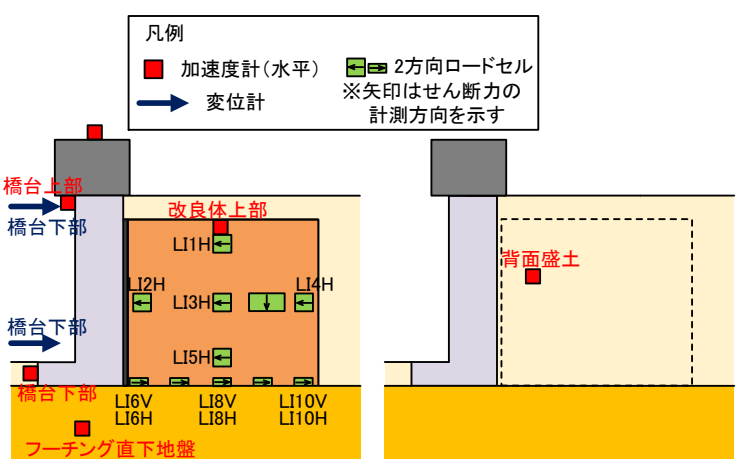

図-5 加速度計・変位計・2方向ロードセルの位置

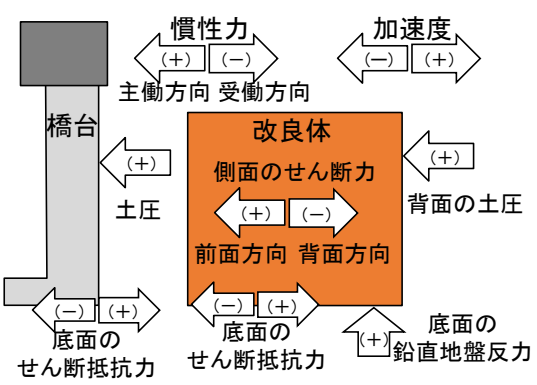

図-6 各計測項目の正負の符号の定義
橋台模型はアルミニウムを使用して見かけの単位体積 重量をコンクリート相当となるよう，橋台模型く体前面 を削る加工を施した（図-4(a)）。また，桁からの慣性力

（実物：桁長 $20 \mathrm{~m}$ 程度のコンクリート桁）を模擬する ために橋台模型の前面側上端に切欠きを 2 箇所設けて, 鉄の重錘（1 箇所当り $72.5 \mathrm{~N} ）$ を設置し，橋台天端にコ ンクリートの重錘（700N）を設けて橋台重量と桁重量 の比を $1.4: 1$ 程度に設定した. 改良体模型は貧配合モ ルタル模型を用いた振動台実験 ${ }^{11)}$ において，剛体挙動を 示し，実験後に損傷は見られなかったことから，剛性の 高い材料を用いても実際の挙動を再現できると判断し, アルミニウムのプレートを組合せて作製した，改良体の 見かけの単位体積重量は $18 \mathrm{kN} / \mathrm{m}^{3}$ と設定した.

橋台と改良体の連結はピン結合を想定し，模型はユニ バーサルジョイントを用いて，改良体上端で連結する構 造とした。 また，連結材に発生する軸力，せん断力を計 測するために，連結部の橋台側に角棒 $(5 \mathrm{~mm} \times 5 \mathrm{~mm})$ を 配置し，2 断面にひずみゲージを貼付した．橋台と改良 体の間に生じる作用力はロードセルで計測することで計 画していたが，改良体とロードセル受圧板の金属同士に よる局所的な接触によって異常な数值になることを防止 するため, 改良体の前面に硬質ゴム $10 \mathrm{~mm}$ を設置した.

また，橋台模型および改良体模型が地盤材料と接する面 には，コンクリートや改良体の地盤との摩擦を模擬して 紙やすり（\#80）を貼り付けた.

計測機器は，実物における軌道の位置（以下，軌道測 線とする）と改良体の位置（以下，改良体測線とする） において加速度計，および変位計を配置した．また，橋 台，改良体に作用する土圧を計測するために，2 方向口 ードセル，および土圧計を配置した。

なお，本論では図-5 に示す加速度計，変位計，2 万方 ロードセルの值を用いる．また，各計測值の正負の符号 の定義を図-6に示す.

\section{（2）加振条件}

加振は JR 東日本研究開発センタ一所有の水平振動試 験装置を用いて重力場により実施した．加振波形は，鉄 道構造物等設計標準・同解説 而震設計 ${ }^{21}$ に示される L2 地震動（スペクトル II）の地表面設計地震動波形のピー ク周波数が $1 \mathrm{~Hz}$ 程度であることをもとに相似則を考慮

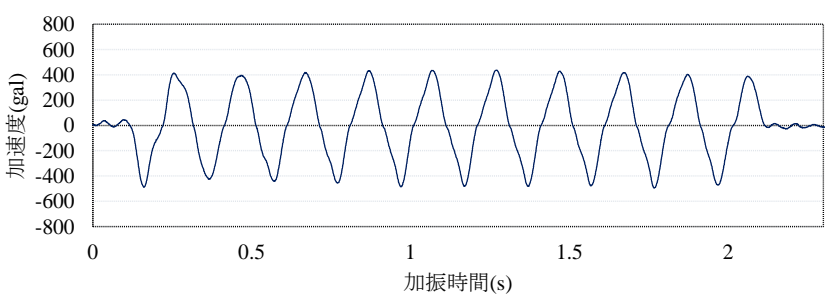

図-7 入力加振波形の 1 例（Case1 500gal 加振） 


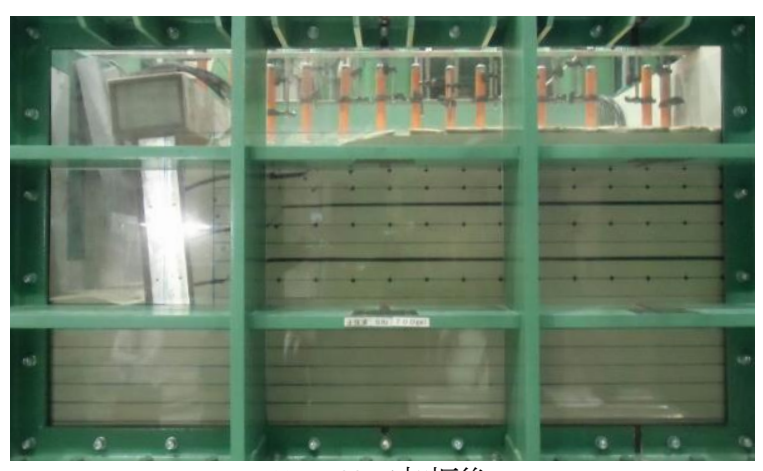

(a) $700 \mathrm{gal}$ 加振後

図-8 Case1 加振後の状況写真

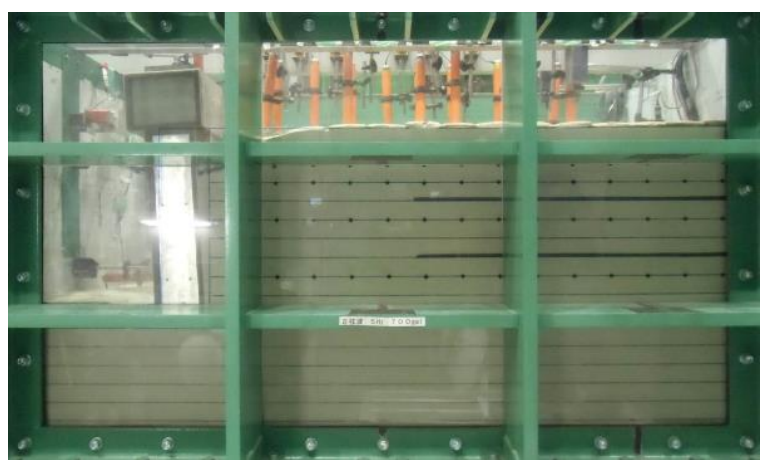

(a) $700 \mathrm{gal}$ 加振後

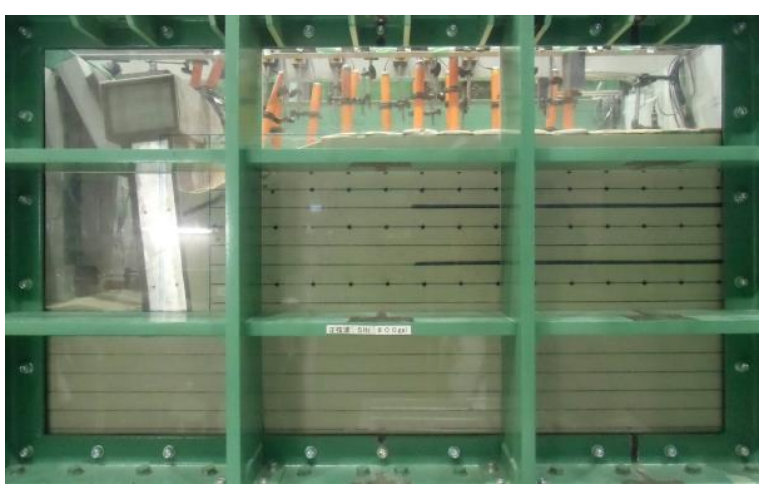

(b) $800 \mathrm{gal}$ 加振後

図-9 Case2加振後の状況写真

して時間補正し，正弦波 $5 \mathrm{~Hz} ， 10$ 波とした．加振ステッ プは，振動台への入力加速度 50gal の加振後, 100gal か らは 1 ステップ 100gal 間隔で段階的に増加させた. 図-7 に，土槽底面の加速度計で計測された入力加速度波形の 1 例を示寸. 加振は, 最終的に試験体の崩壊形状が明確 になるところまで行い, Case1 では 700gal, Case2 では 800gal，Case3では 1100gal，Case4では 900gal まで行った。 なお，本論文で「○gal 加振」と示寸加速度は振動台の 目標加速度を示しており，実際に入力されている加速度 とは若干の増減がある。

\section{4. 実験結果と考察}

（1）橋台 - 背面盛土の崩壊状況

図-8〜11 は Case1〜4 の 700gal 加振後, および最終加

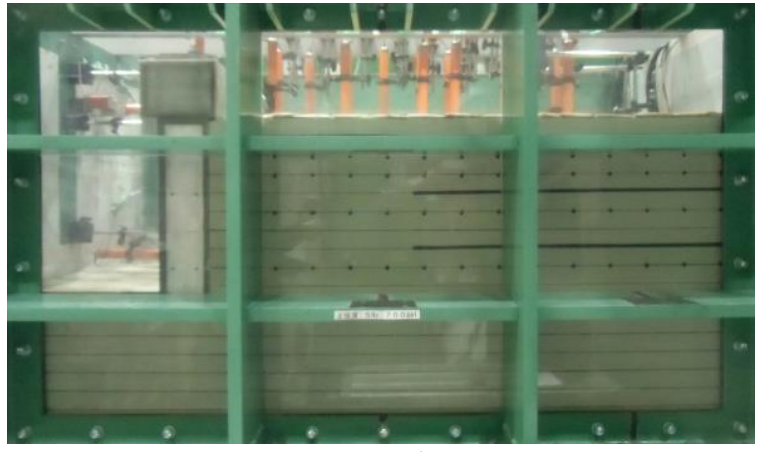

(a) $700 \mathrm{gal}$ 加振後

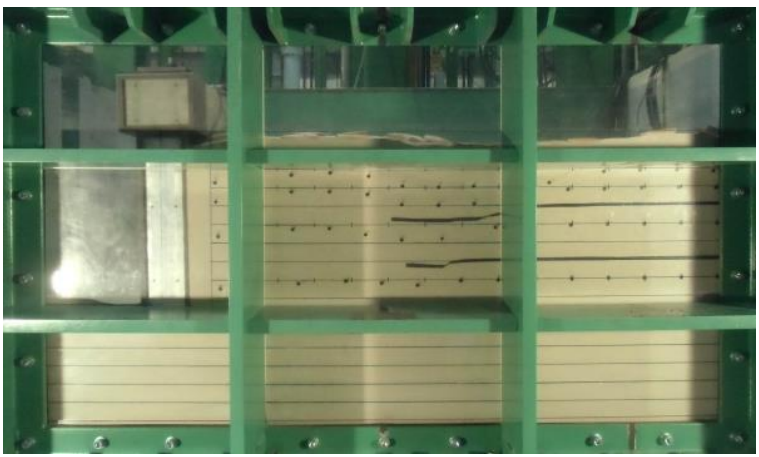

(b) $1100 \mathrm{gal}$ 加振後

図-10 Case3 加振後の状況写真

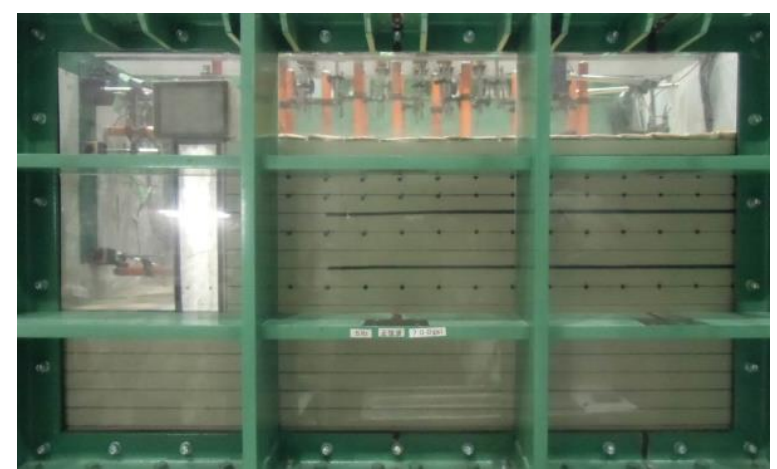

(a) 700gal 加振後

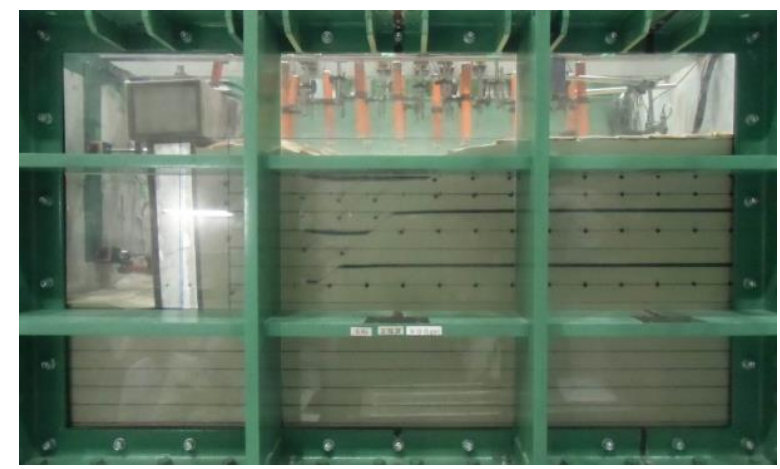

(b) $900 \mathrm{gal}$ 加振後

図-11 Case4加振後の状況写真

振後における橋台，背面盛土の状況写真であり，図-12 は最終加振後の崩壊状況のスケッチとアクリル側面に設 置した標点の残留変位から求めた変位ベクトルを示して いる. Case1，Case2 では橋台の背面下端からすべり面が 


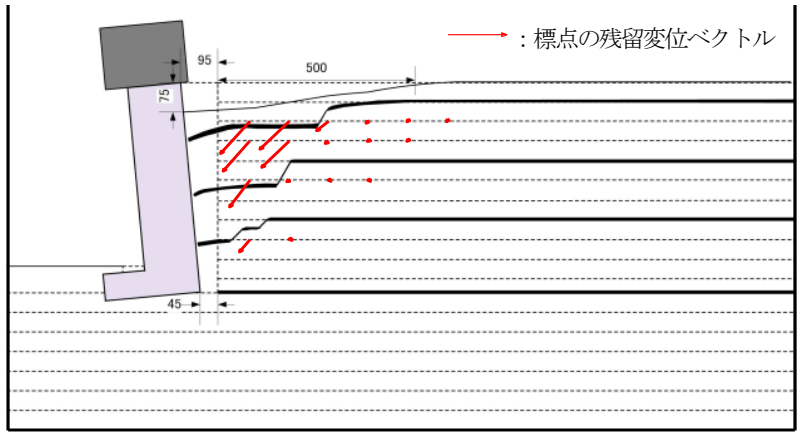

(a) Case1（700gal 加振後）

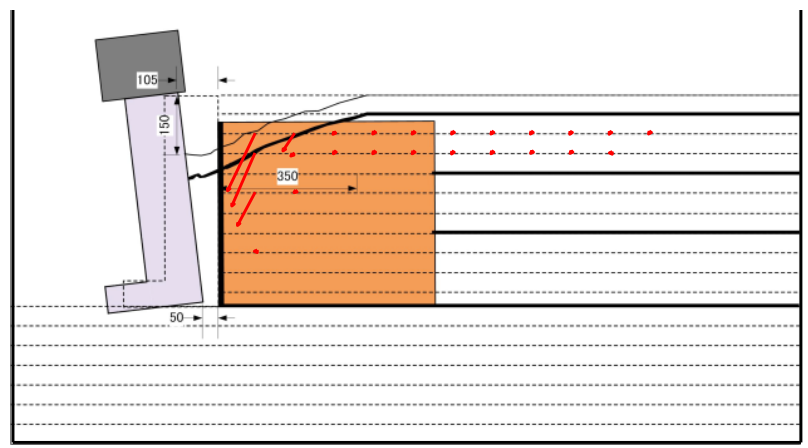

(b) Case2（800gal 加振後）

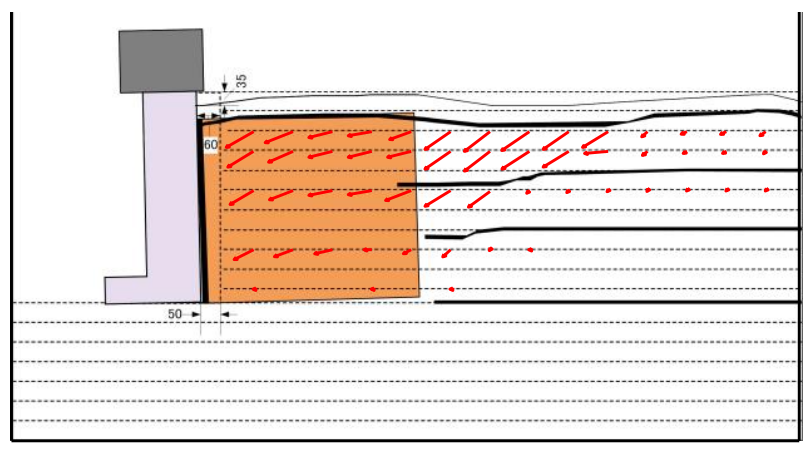

(c) Case3（1100gal 加振後）

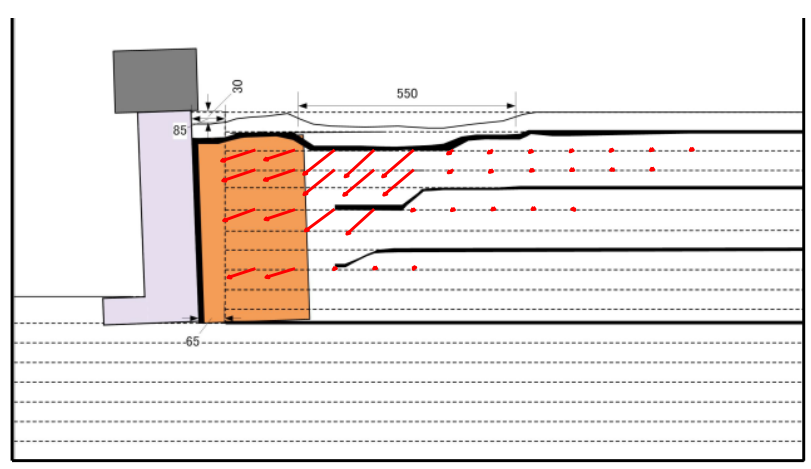

(d) Case4 (900gal 加振後)

図-12 最終加振後の崩壊形態

生じて，橋台の傾斜，滑動に伴って橋台近傍の背面盛土 が沈下した．なお，Case2 の崩壞後における改良体の変 位は極めて小さかった。 それに対して, Case3，4では， 橋台と改良体が一体で挙動して，崩壊形態は滑動モード により崩壊した. Case3，4では橋台近傍において，背面 盛土に若干の沈下は生じていたが，改良体で挟まれた範 囲の背面盛土の沈下量は小さく, 改良体背面側の盛土に

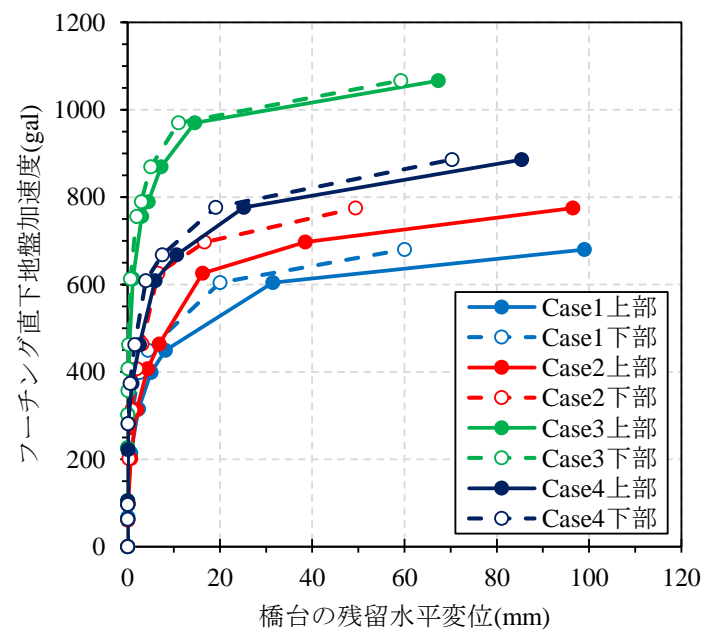

(a)

フーチング直下地盤加速度と橋台の残留水平変位の関係

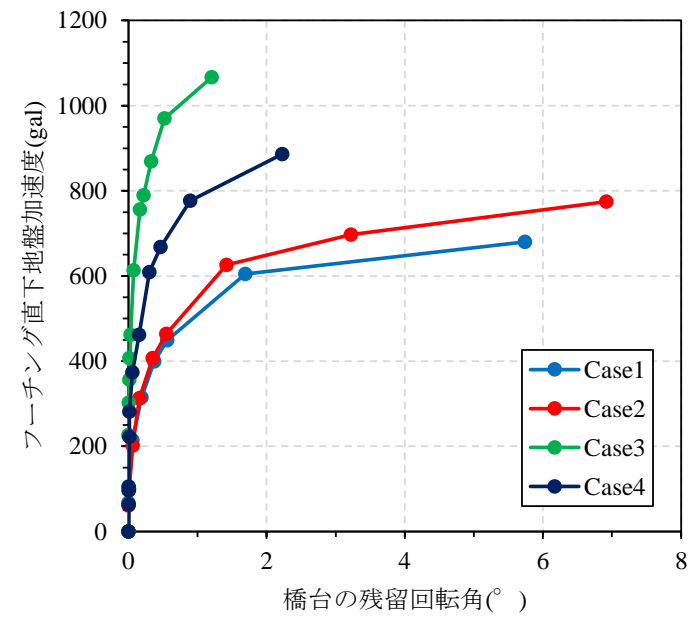

(b) フーチング直下地盤加速度と橋台の残留回転角の関係 図-13 残留変位の比較

すべり面が生じて，その範囲が沈下した．また，Case3 の崩壊後における改良体は，僅かながら背面側が浮き上 がる挙動となっていた。

\section{(2) 橋台の残留変位}

図-13(a)，(b)は，各加振ステップ後における橋台の 上・下部における残留水平変位, および残留回転角とフ 一チング直下地盤における最大加速度（主働方向の慣性 力）の関係を示したものである. 残留水平変位は Case1, 2では 400gal，Case3 では 900gal，Case4 では 700gal 程度か ら増加しはじめる傾向となった。同じ加速度（例えば 600gal）で比較すると, Case3, Case4, Case2, Case1 の順 序で変位が大きくなっている. 残留回転角も残留水平変 位と同様の傾向であるが，Case1，2 に比べて Case3，4 の残留回転角は非常に小さい。これは，改良体の連結に よって, 橋台上部の変位が抑制され, 崩壊形態が滑動モ ードになっためである.

これらの結果から，橋台と改良体の連結により，改良 体を連結しないものに比べて，而震性が向上することを 


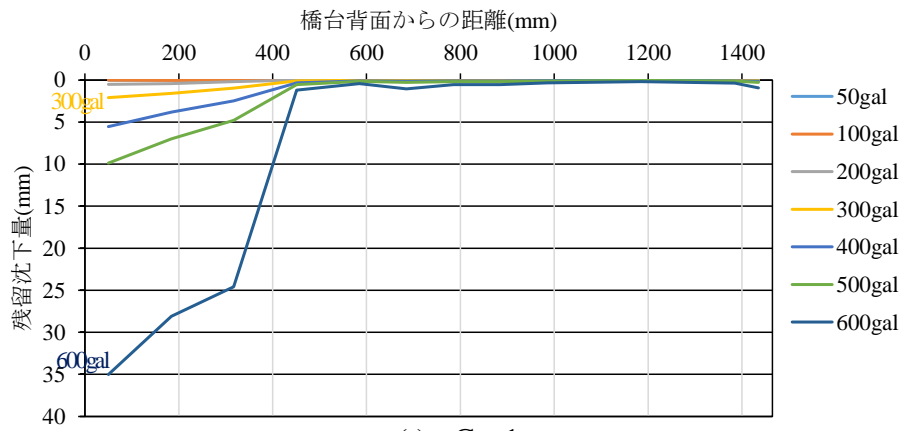

(a) Case1

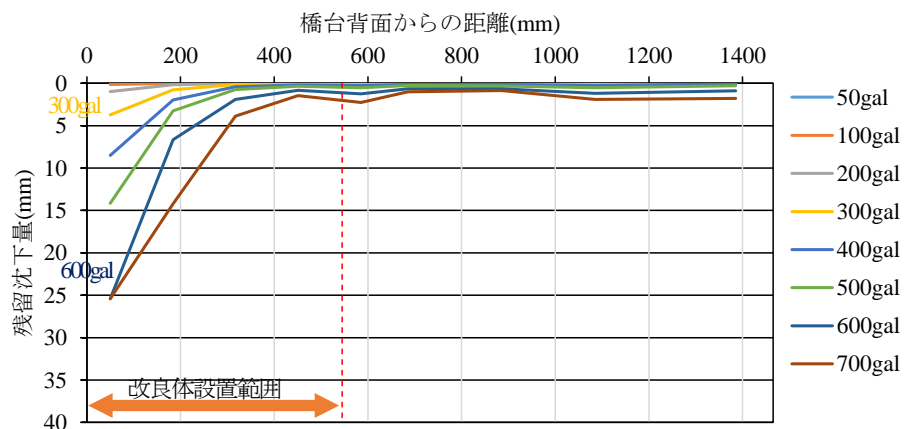

(b) Case2

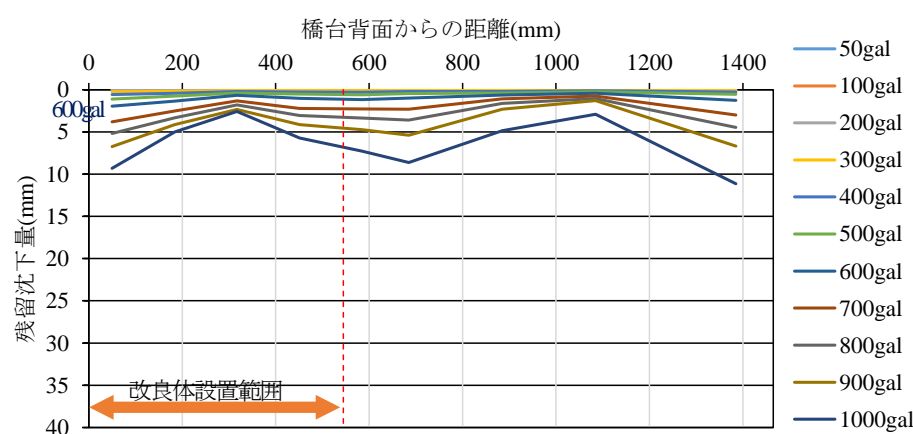

(c) Case3

橋台背面からの距離 $(\mathrm{mm})$

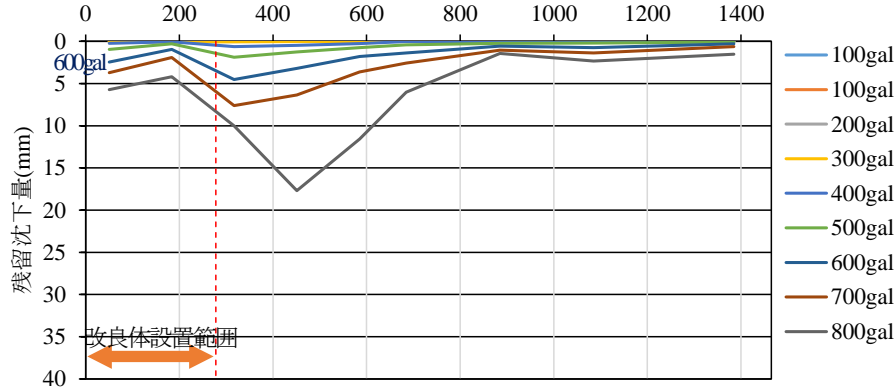

(d) Case4

図-14 背面盛土の残留沈下量分布

確認した．改良体を連結した場合における Case3，4 を 比較すると，改良体の長さの大きいものほど而震性が高 くなっており，これは，補強対象とする既設橋台の耐震 性に応じて，必要な改良体の長さを設定可能なことが示 唆される.

\section{(3) 背面盛土の沈下量}

図-14 は，各ステップにおける軌道測線位置での背面 盛土の残留沈下量分布を示したものであり，横軸は橋台

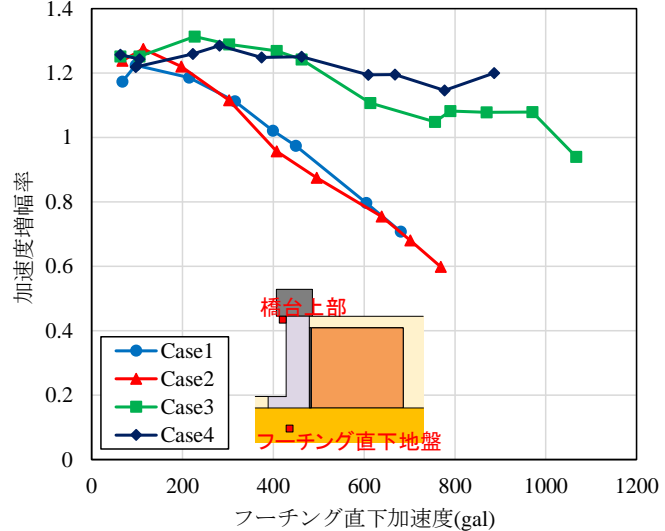

(a) 橋台上部の加速度増幅率

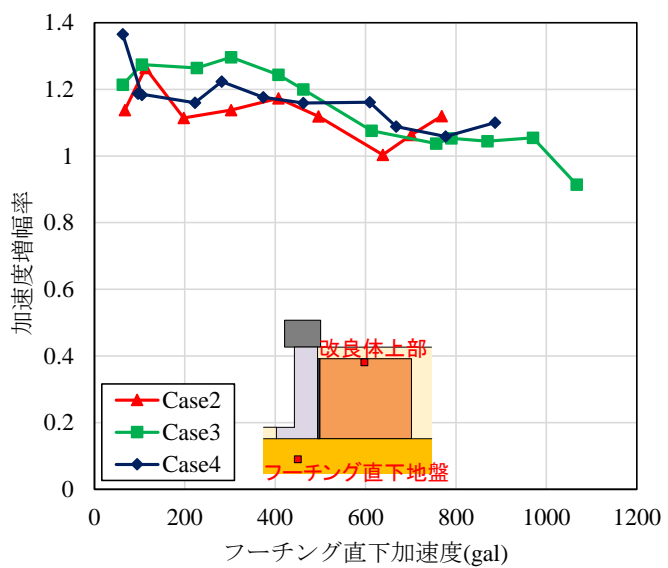

(b) 改良体上部の加速度増幅率

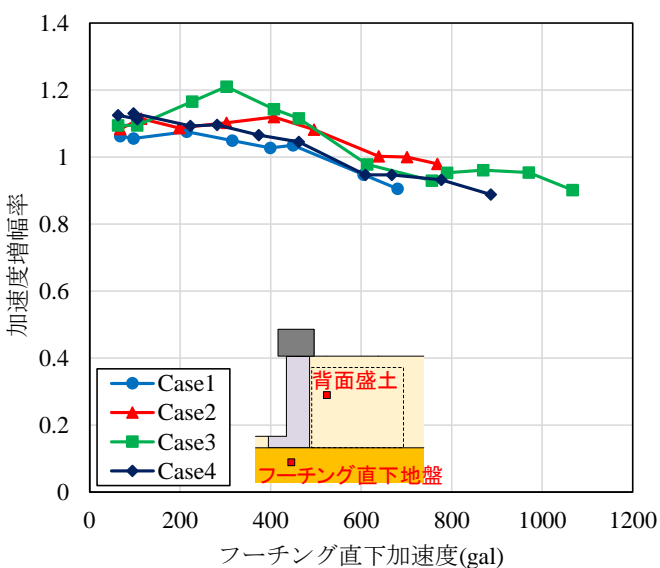

(c) 背面盛土の加速度増幅率

図-15 応答加速度の増幅率

背面位置からの距離で整理している. Case1，2 では 300gal 加振以降に橋台背面からすべり面の範囲（図-12） において沈下量に増加が見られる. Case3，4 では橋台背 面近傍において沈下は見られるが，改良体設置範囲では 沈下は小さく，改良体背面に発生したす心゙り面の範囲に おいて，沈下が生じている。

鉄道構造物等設計標準・同解説 而震設計 ${ }^{21)}$ では，橋 台背面盛土の復旧性について，橋台と背面盛土の沈下差 を照査することが示されている，橋台の残留水平変位に 応じて背面盛土が沈下寸る場合は，橋台近傍が局所的に 
沈下するよりも，沈下量を線路方向に分布させることで 橋台と背面盛土の沈下差を抑制することが可能となる. また，各ケースの残留沈下量を 600gal 加振後で比較する と橋台背面近傍では Case1, Case2, Case4, Case3 の順序 で小さくなっており，改良体の設置や改良体を連結する ことによる背面盛土の沈下抑制効果が確認された。なお, Case2 の 800gal 加振後において，すべり面以遠での残留 沈下量は $2 \mathrm{~mm}$ 程度であり, 盛土自体の摇すり込み沈下 量は橋台の変形に伴う沈下量に比べて僅かであった。

\section{（4）応答加速度の増幅特性}

図-15 はフーチング直下の地盤加速度に対する橋台上 部，改良体上部，背面盛土の加速度の増幅率を示したも のである. 加速度は各加振ステップにおいて慣性力主働 方向に最大となる数值を用いた．改良体上部，および背 面盛土では，いずれのケースにおいても加速度の増加に よる加速度増幅率の変動は小さく，概ね同程度の数值と なっている，それに対して橋台上部では，残留変位が生 じていない 50，100galまでは，いずれのケースにおいて も加速度増幅率は概ね同程度であるが，200gal 以降では Case1， 2 と Case3，4 の増幅率の傾向は異なっている. Case1， 2 では，加速度の増加に伴い増幅率は低下し， 400gal よりも大きい加速度では，増幅率は 1.0 よりも小 くなっている.これは, Case1, 2 と Case3, 4 の崩壊モ

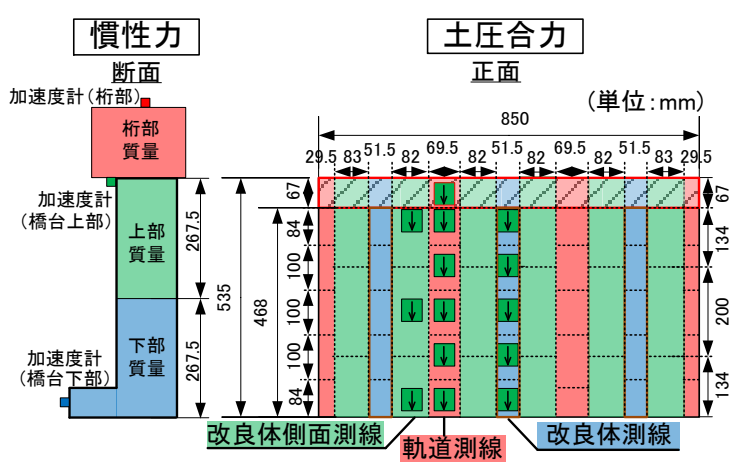

(a) 慣性力・土圧の算定

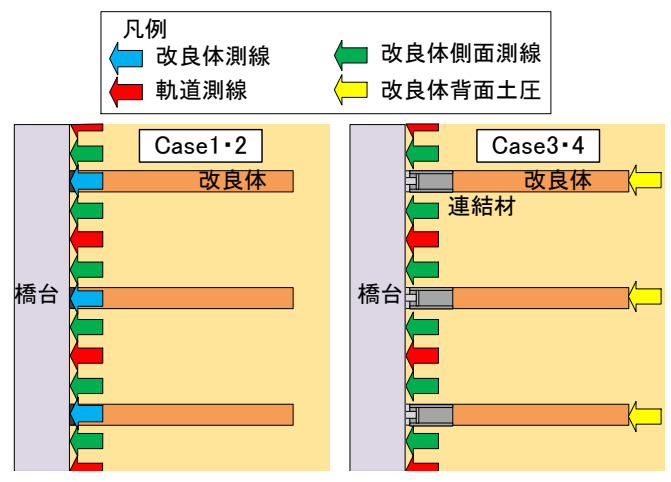

(b) 連結材有無による土圧合力の算定

図-16 橋台に作用する慣性力・土圧の算定方法
一ドの違いによる影響であると推測される。Case3，4 では加速度の増加による増幅率の変動は小さく, 改良体 や背面盛土と同様の傾向を示した。これは，橋台と改 良体を連結することにより，橋台，改良体，背面盛土が 一体で挙動するためであると考えられる．また，Case1， 2 の橋台の増幅率は概ね一致していることから，改良体 を連結しない場合は，無対策のものと応答特性は変わら ないことが分かる.

\section{(5) 慣性力と土圧の比較}

橋台に作用する慣性力，および土圧を比較するため, 慣性力，土圧の算出方法について，文献 22)を参考に整 理した．慣性力は図-16(a)に示すように橋台模型を桁部, 上部，下部に 3 分して，各箇所に設置した加速度計の数 值に，各々対応する質量を乗じて求めた，土圧は，水平 方向に作用する土圧合力（以下，土圧合力と称する）を

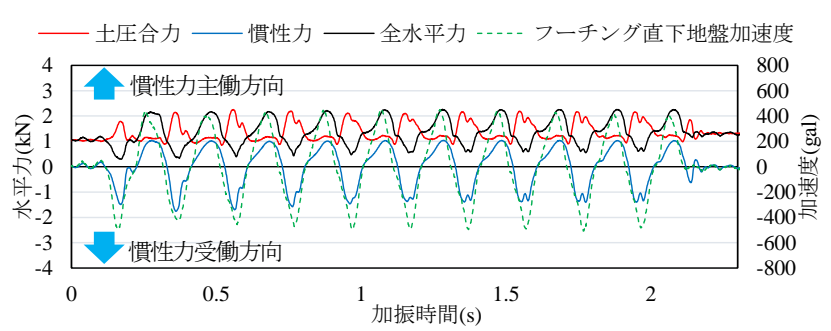

(a) Casel

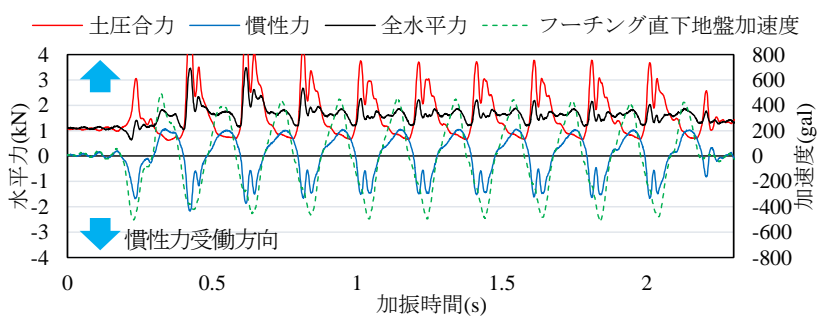

(b) Case2

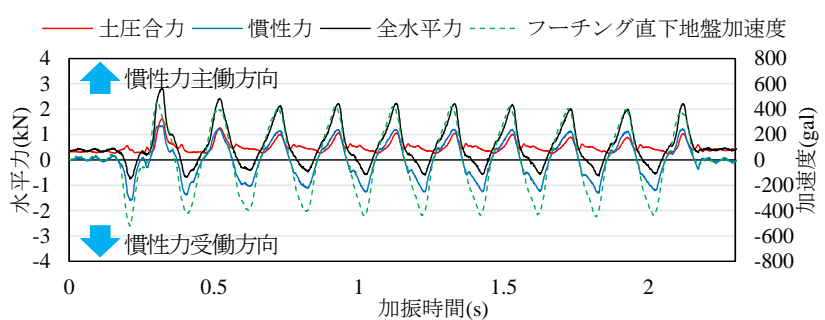

(c) Case3

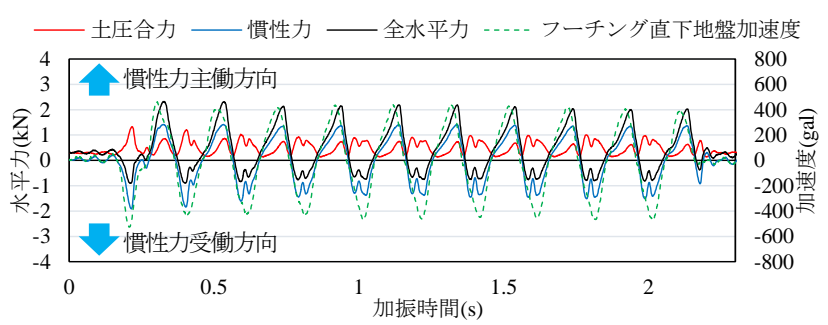

(d) Case4

図-17 水平力の時刻歴波形（500gal加振） 
算出することとし，図-16 (b)に示すように Case1，2 は橋 台背面全体に作用寸る土圧合力，Case3，4 は橋台と改良 体が一体で挙動するため, 改良体間の背面盛土から作用 する土圧と改良体背面に作用する土圧の合力で評価した. 土圧合力の算出は, 橋台模型の背面に設置した 2 方向口 一ドセルの水平土圧成分，および改良体背面に設置した 土圧計の数值から図-16 (a)に示寸各計器の負担面積を乗 じて求めた. なお，土圧合力は模型構築時の初期土圧分 を加えている．また，慣性力と土圧合力の和を橋台に作 用する全水平力として評価した.

図-17 は Case1〜4の 500gal 加振時における慣性力, 土 圧合力，全水平力，およびフーチング直下加速度の時刻 歴波形を示したものである. Case1 では慣性力と土圧合 力の位相は 180 度異なっており, 既往の実験 ${ }^{11)}$ における 桁重量が大きい場合の実験結果と同様の傾向となってい る.この挙動は，慣性力が受働方向（負側）に最大とな るときに橋台が背面盛土側に衝突するようにして大きな 土圧を発揮し, 逆に慣性力が主働方向（正側）に最大と なるときには橋台が背面盛土から離れるために土圧が加 振前よりも小さくなると考えられている.

Case2 では, 慣性力の主働方向最大時に土圧合力は最 小值を示し，土圧合力は Casel のものに比べて小さくな っている．また，慣性力の受働方向最大時には土圧合力 が最大值を示している．詳細は後述するが，これは慣性 力の主働方向最大時には, 改良体によって土圧を低減さ せる効果が働き, 慣性力の受働方向最大時には, 橋台が 背面盛土側に応答する際に改良体と衝突することで大き くなるものと考えられる.

これらの挙動に対して, Case3，4 は異なり, 慣性力 主働方向最大時に土圧合力が最大值を示し, 慣性力と土 圧合力は同位相で作用している．また，慣性力受働方向 最大時においても土圧合力は増加する挙動となっている.

次に各ケースにおいて, 入力加速度波形となるフーチ ング直下地盤加速度と慣性力, 土圧合力, および全水平 力の波形を慣性力主働方向で比較する. 慣性力と全水平 力は, Case1，2，4 ではフーチング直下地盤加速度と若 干の位相差が生じ, Case3 では位相が一致している。こ れは，図-13 に示すように 500gal 程度では, Case1，2，4 は残留変位が生じていることから, 残留変位に伴い位相 差が生じたものと考えられる．また，土圧合力とフーチ ング直下地盤加速度の波形を比較すると Case1，2 では 逆位相となっており，これは先述した慣性力と土圧の位 相関係と同様の理由であると考えられる. Case4 では慣 性力主働方向における土圧合力とフーチング直下地盤加 速度のピークに時間のずれが生じている.これは, フー チング直下地盤の入力加速度に対して, 橋台と背面盛土 が一体となって挙動せず, 両者の応答変位に差が生じる ためであると考えられる，それに対して，橋台と背面盛
土が一体で挙動している Case3 では, 入力加速度に対し て橋台と背面盛土の応答変位に差が生じないため, 土圧 合力とフーチング直下地盤加速度の位相は一致したと考 えられる。

図-18 は，各加振ステップにおける慣性力，土圧合力, 全水平力の時刻歴波形から，慣性力の主働方向作用時に 全水平力が最大となる時刻の慣性力と土圧合力を示した ものである. 土圧合力は, 修正物部岡部式により, 背面 盛土の物性值（表-1 の数值を $c=0$ 法により設定）を用い て，水平成分の土圧を算出した值も示している．なお，

Case3，4 に関しては，全水平力の最大時における改良体 の慣性力（改良体上部，下部に設置した加速度計の平均 值に質量を乗じて算定）を同図に示した

図-18(a)から, 慣性力はフーチング直下地盤加速度が 100～200gal 程度までは，各ケースともに同程度の数值 であるが，それ以降は，Case1，2 と Case3，4 は異なる 傾向となっている.これは, 4.(4)で述べた崩壊モードの 違いによるものであると考えられる。 また，橋台に対 して改良体の慣性力を比較すると Case3 では $1 / 4$ 程度,

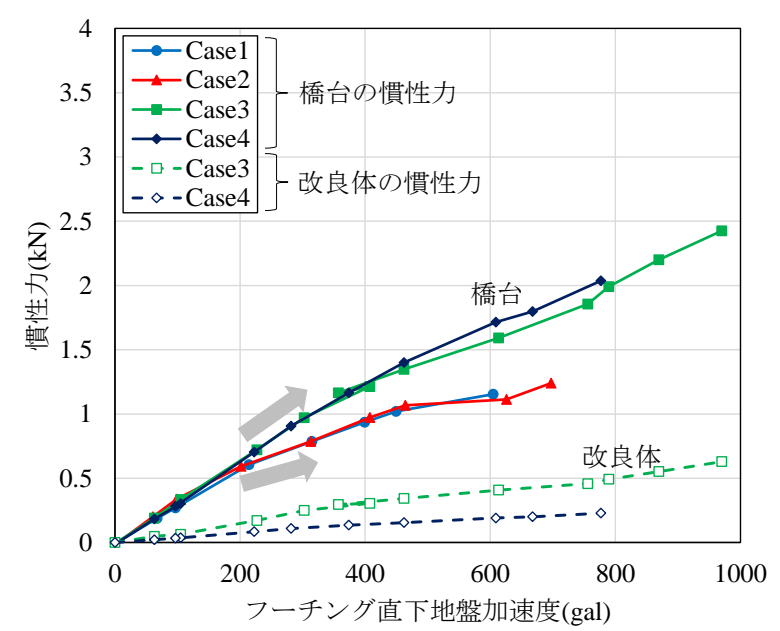

(a) 慣性力

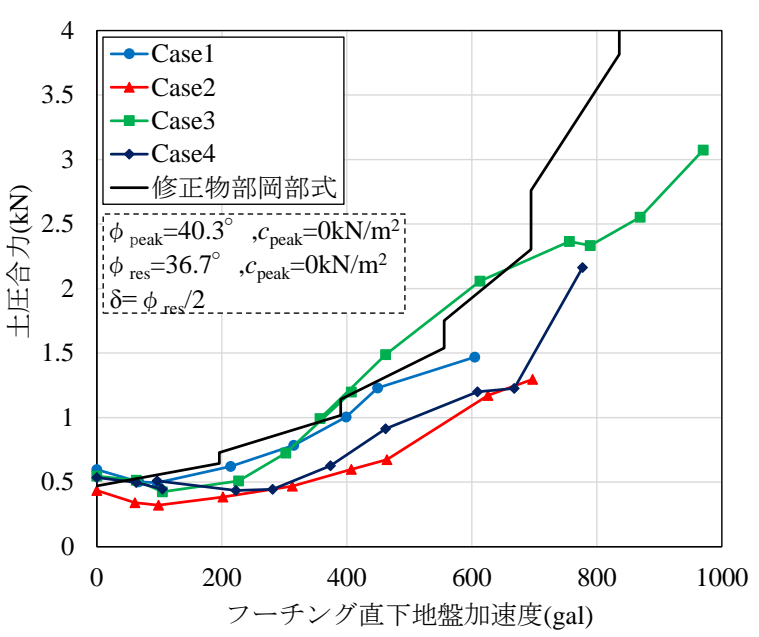

(b) 土圧合力

図-18 橋台に作用する水平力の比較 


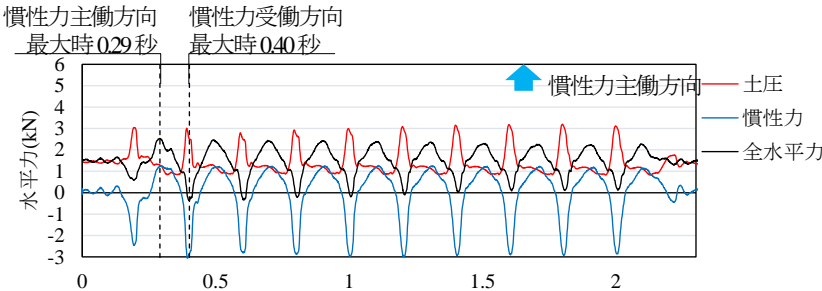

(a) 水平力 (土圧合力 $\cdot$ 慣性力 - 全水平力)

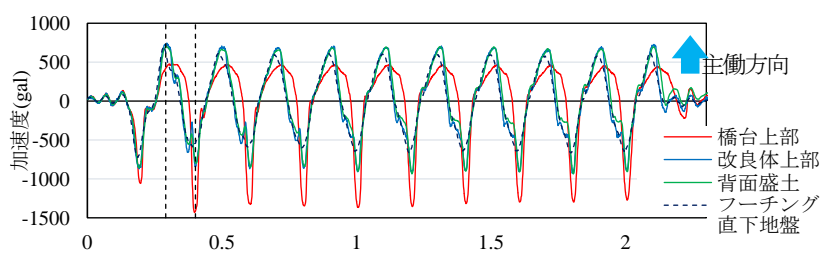

(b) 橋台 - 改良体 - 背面盛土の応答加速度

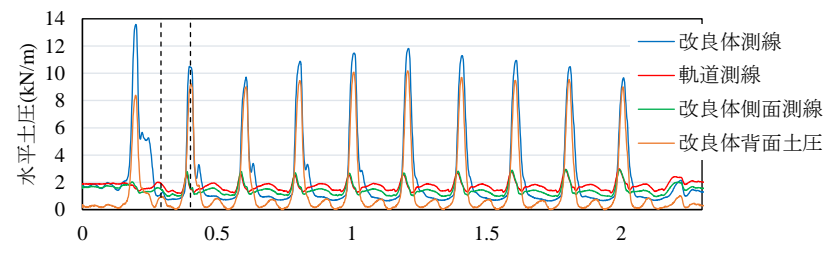

(c) 各測線の水平土圧

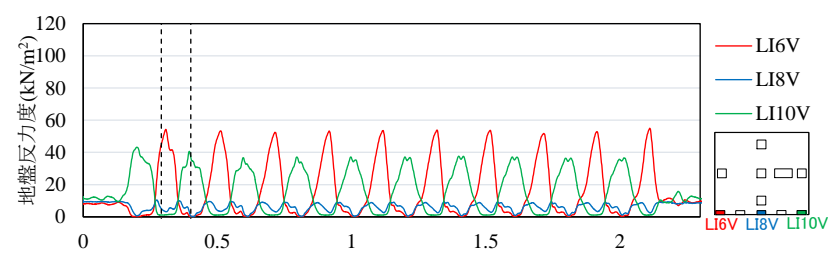

(d) 改良体底面の地盤反力度

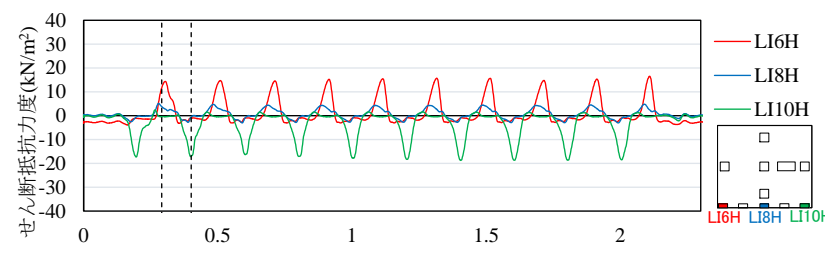

(e) 改良体底面のせん断抵抗力度

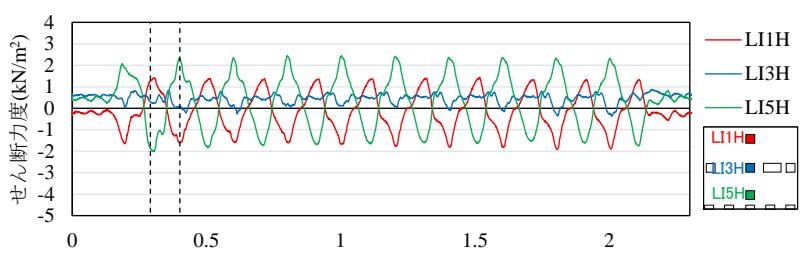

(f) 改良体側面のせん断抵抗力度

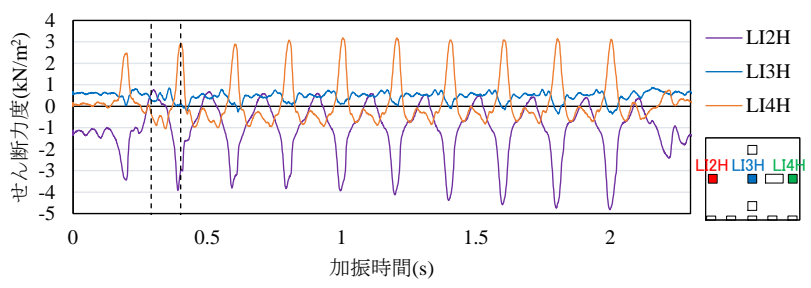

(g) 改良体側面のせん断抵抗力度

図-19 時刻歷波形 (Case2 - 700gal)

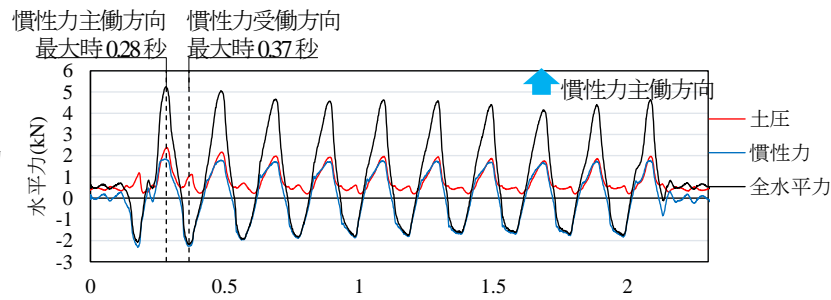

（a）水平力（土圧合力 ・ 慣性力 - 全水平力）

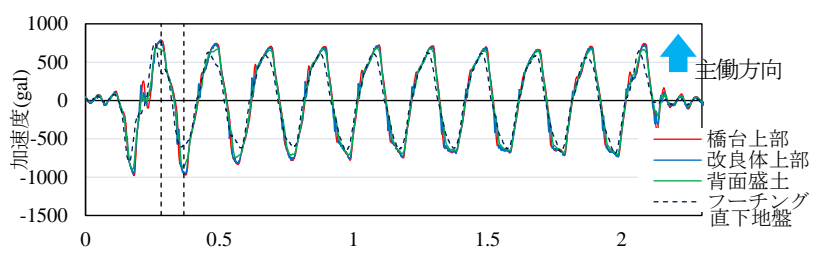

(b) 橋台・改良体・背面盛土の忘答加速度

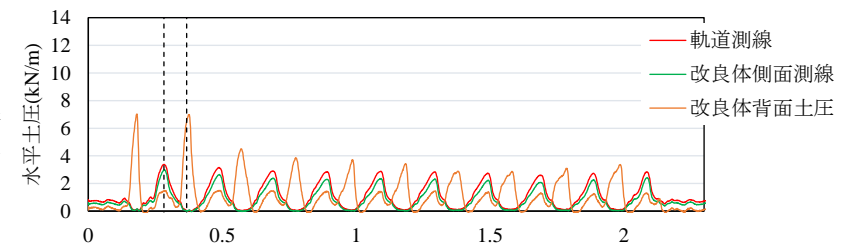

(c) 各測線の水平土圧

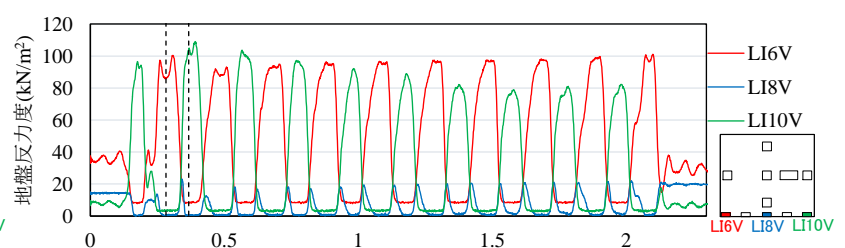

(d) 改良体底面の地盤反力度

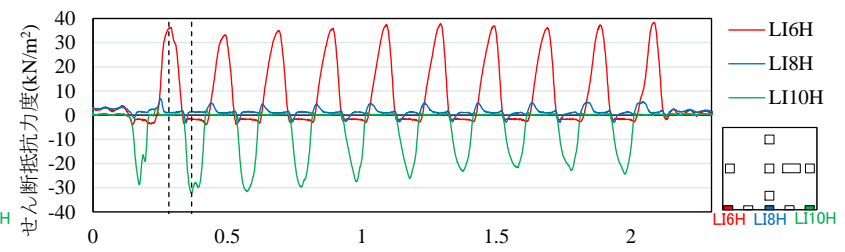

(e) 改良体底面のせん断抵抗力度

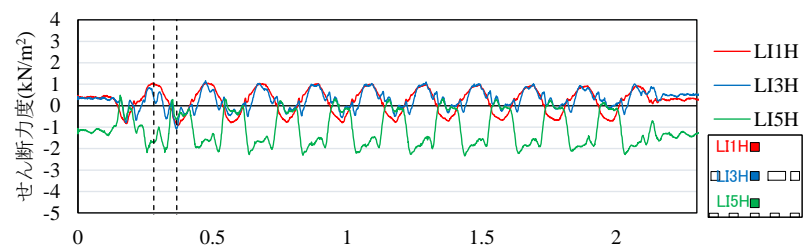

(f) 改良体側面のせん断抵抗力度

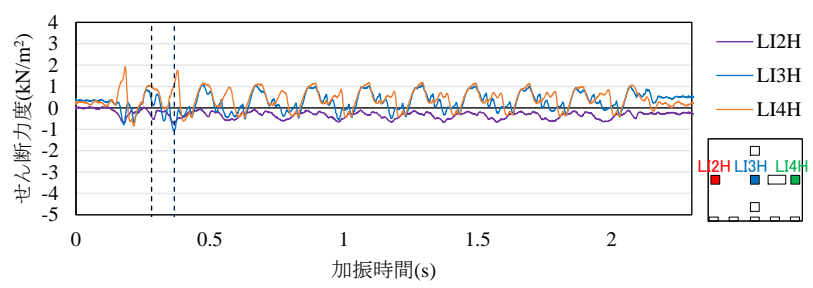

(g) 改良体側面のせん断抵抗力度

図-20 時刻歴波形 (Case3 $\cdot 700 \mathrm{gal})$ 


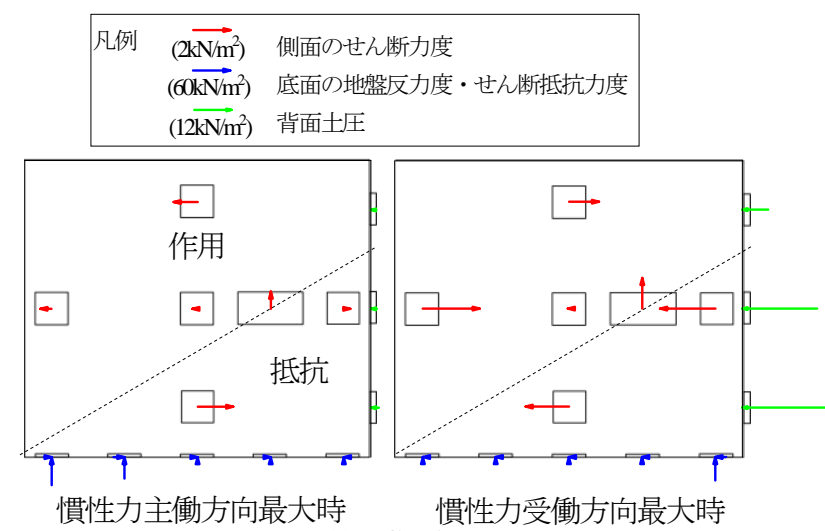

(a) Case2

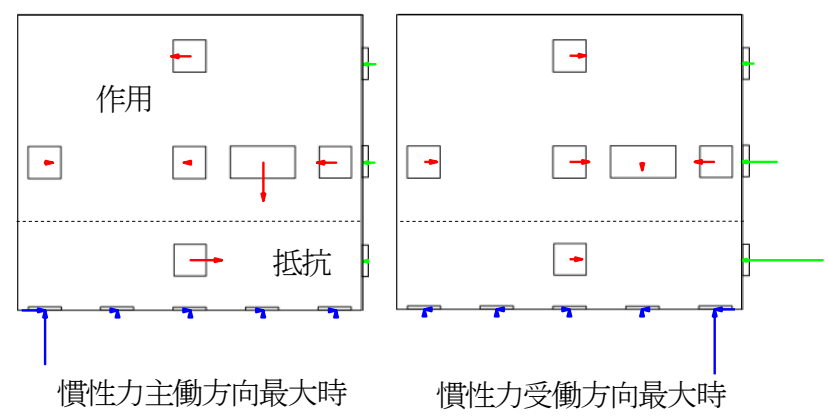

(b) Case3

図-21 改良体に働く作用力と抵抗力（700gal 加振）

Case4 では $1 / 8$ 程度の大きさで改良体に作用することが 分かる.

土圧合力に関しては，図-18(b)から，Case1，3 は修正 物部岡部式と同程度の大きさを示し, Case2，4 は修正物 部岡部式よりも小さな土圧となった. Case3 に関しては 図-17 のように慣性力と土圧合力が同位相で作用するた め，土圧が大きくなるものと考えられる. Case2 は修正 物部岡部式よりも小さな值となっており, 既往の研究 ${ }^{3)}$ のように土圧低減効果が働いたためであると考えられる.

\section{(6) 連結の有無による時刻歴波形の比較}

図-19，20 は，改良体の連結の有無による作用力と抵 抗力を比較するため, Case2, 3 の 700gal 加振時における 各計測值の時刻歷波形を示したものである.

図-19(b)，20(b)は，橋台，改良体，背面盛土，および フーチング直下地盤の加速度時刻歷波形を示したもので ある. Case2 では改良体と背面盛土の応答加速度は同位 相であるが，橋台は，位相差が生じている．それに対し て，Case3 では，橋台，改良体，および背面盛土は同位 相となり，一体で挙動していることが分かる．また，フ 一チング直下地盤に対する橋台上部，改良体，および背 面盛土の加速度波形を比較すると, Case2 では橋台上部 とフーチング直下地盤は位相差が生じ，橋台上部の応答 が小さくなっている，また，改良体，および背面盛土に おいても若干の位相差が生じている。 これは, 図-13 か ら 700gal 程度では, Case2 では残留変位が大きいことが
原因であると考えられる. Case3 も同様に 700gal 程度で は残留変位が生じており, フーチング直下地盤と橋台 上部，改良体，および背面盛土の波形には，若干の位 相差が生じている.

図-19(a)，20(a)は，土圧合力，慣性力，および全水平 力の時刻歴波形，図-19(c)，20(c)は，各測線の土圧，お よび改良体背面に作用する土圧の時刻歴波形を示した ものである. 図-19(a)から, Case2 では, 図-17(b) と同様 に慣性力の受働方向最大時に土圧合力が最大值となっ ている.これは, 図-19(c)から, 同時刻において改良体 測線，および改良体背面の土圧が最大值となっている ことから，橋台が背面盛土側に応答する際に改良体と 衝突して改良体測線の土圧が大きくなり，改良体が背 面側に押されることで改良体背面の土圧も大きくなっ たものと考えられる. Case3 では慣性力の主働方向最大 時に軌道測線, 改良体側面測線の土圧が最大值を示し ており，Case2 よりも大きな值となっている．また，慣 性力の受働方向最大時には改良体が背面側に押される ことで改良体背面の土圧が大きくなっている.

図-19(d)〜(e)，20(d)〜(e)は，改良体底面に生じる地盤 反力度, せん断抵抗力度, および改良体側面に生じる せん断力度の時刻歴波形である. また, 図-21 は慣性力 の主働方向最大時, 受働方向最大時における改良体の各 計測位置でのベクトル図を示す.

図-19(d)，(e)，20(d)，(e)，および図-21 から，改良体底 面の地盤反力度は, 慣性力の主働, 受働方向に応じて, 回転変形に対する抵抗力が生じている.また，改良体底 面のせん断抵抗力度は, 慣性力の主働・受働方向に応じ て，滑動の抵抗となる方向に生じている．以上のことか ら，改良体は回転，および滑動に対して，底面の鉛直地 盤反力，およびせん断抵抗力で抵抗していることが分か る. また, その数值は Case2 よりも Case3 のほうが大き くなっていることから，連結することにより，改良体の 底面の抵抗力が，大きく発揮されるものと考えられる。

図-19(f)，(g)，20(f)，(g)，および図-21から，改良体の 連結の有無によって, 改良体側面のせん断力の挙動が異 なっている. 改良体側面のせん断力は, 改良体に挟まれ た背面盛土のせん断変形やすべり，すり抜け挙動によっ て，改良体に作用力や抵抗力として複雑に生じているも のと考えられる. 図-21(a)から, Case2 の慣性力主働方向 最大時では，すべり面内の範囲に作用，すべり面外に抵 抗となるせん断力が働いているものと推定される.また， 慣性力受働方向最大時には, 慣性力の最大時とは逆方向 のせん断力が生じている. 次に図-21(b)から, Case3 の慣 性力主働方向最大時では, 上部 $2 / 3$ の範囲に前面方向の せん断力, 下部 $1 / 3$ の範囲には, 背面側に抵抗となるせ ん断力が生じている. 前面方向に生じるせん断力の大き さは，図-20 (g)から橋台に近づく位置ほど，小さくなる 


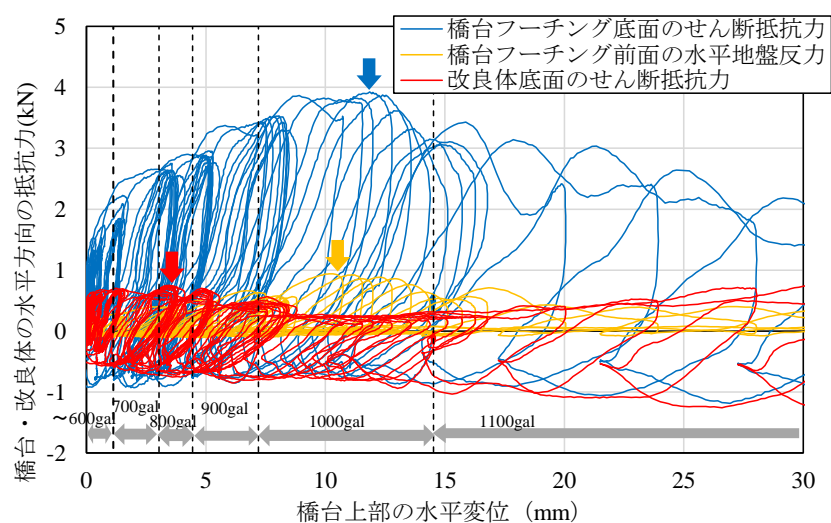

(a) 橋台・改良体の水平方向の抵抗力

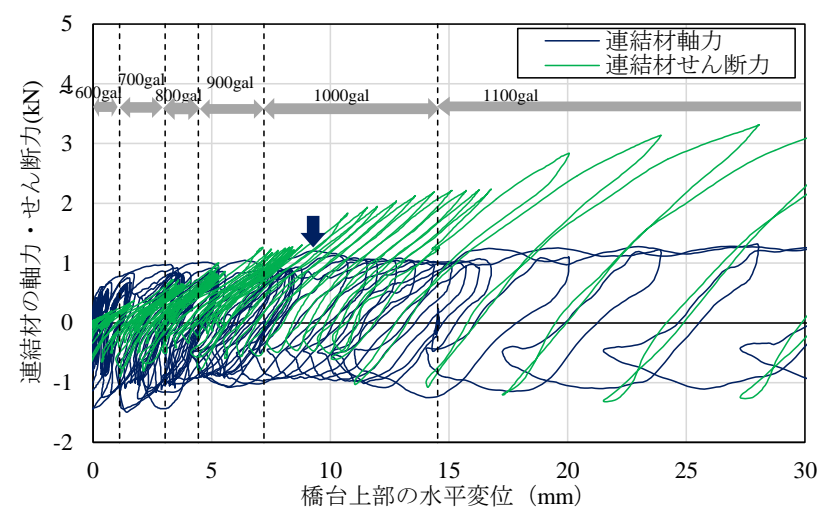

(b) 連結材に発生する断面力

図-22 橋台・改良体底面のせん断抵抗力・連結材に 発生する断面力 (Case3)

傾向にある．これは，背面盛土のせん断変形，もしくは すり抜けしようとする挙動に対して，連結された橋台に より，その挙動が抑制されるためであると考えられる.

\section{（7）橋台 - 改良体底面の抵抗力と連結材の発生断面力}

Case3，4 は崩壊形態が滑動モードであるため，滑動に 対して水平方向の抵抗力となるフーチング底面, 改良体 底面のせん断抵抗力，およびフーチング前面の水平地盤 反力と連結材の発生断面力を整理した. 図-22,23 は,

Case3，4 における上述の抵抗力，および連結材の断面力 と橋台上部の水平変位の関係を示したものであり，最大 值（最終加振時を除く）を知印で示している. フーチン グ底面，改良体底面のせん断抵抗力，およびフーチング 前面の水平地盤反力は， 2 方向ロードセルの計測值に負 担長さに乗じ，合力值を示している．また，連結材の発 生断面力は，3箇所の合力值で示している.

図-22 から, Case3 では橋台上部の水平変位が $3 \mathrm{~mm}$ 程 度において, 改良体底面のせん断抵抗力が最大值に達し た後に，フーチング前面の水平地盤反力，フーチング底 面のせん断抵抗力の順序で最大值となり, その後, 変位 が増大している. 改良体底面のせん断抵抗力は, 最大值

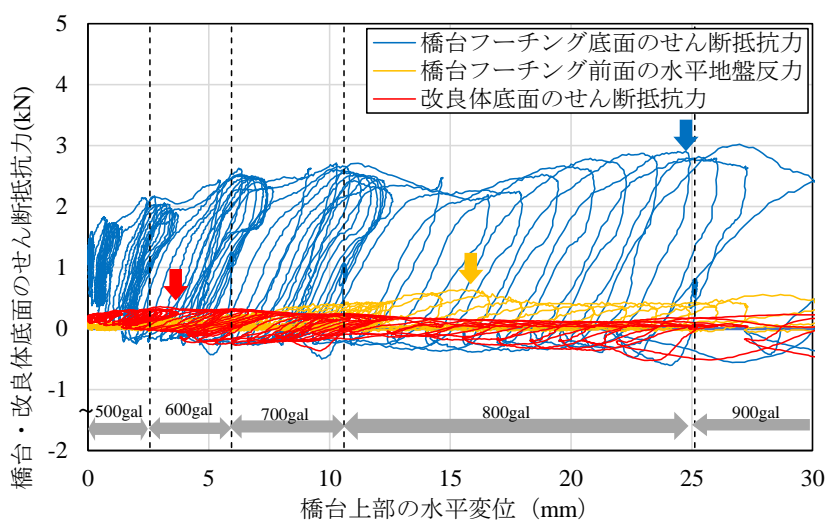

(a) 橋台・改良体の水平方向の抵抗力

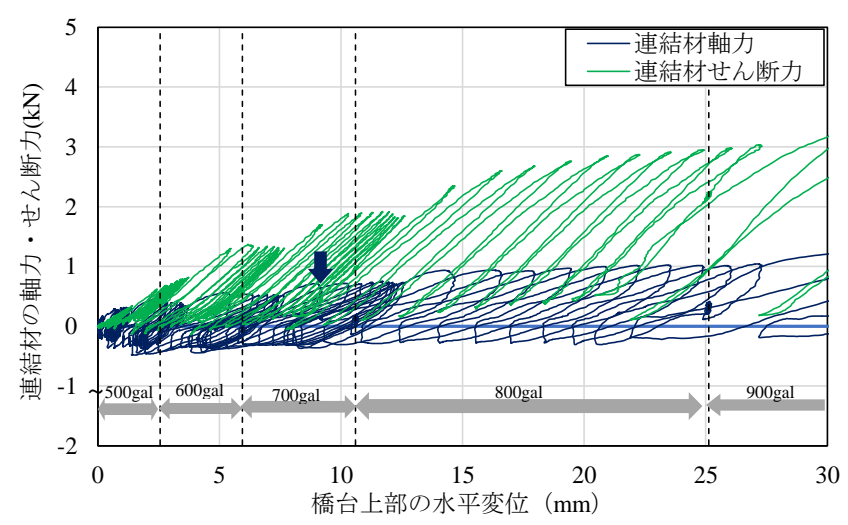

(b) 連結材に発生する断面力

図-23 橋台・改良体底面のせん断抵抗力・連結材に 発生する断面力 (Case4)

を示した後も大きな低下はなく，一定の抵抗力として働 いている. 連結材の軸力は, 改良体底面のせん断抵抗力 の最大值の後に最大值となり, その後も大きな低下はな く抵抗力として働いている，連結材の軸力は，改良体底 面のせん断抵抗力よりも大きな值となっていることから， 改良体の抵抗力としては，底面のせん断抵抗力のほかに 側面のせん断抵抗力も働いているものと考えられる.こ れらの傾向は Case4 も同様である.

Case3 と Case4 を比較すると改良体底面のせん断抵抗 力，および連結材に生じる軸力は，改良体の長さに依存 して Case3 よりも Case4 は小さくなっている. また，連 結材のせん断力は, Case3, 4 ともに橋台上部の変位に応 じて増加する傾向となっており，その数值は Case3，4 で同程度である．連結材のせん断力は，橋台の回転変形 に伴い，改良体が引き上げられようとする挙動に対して， 改良体の重量および改良体の側面, 背面に働く鉛直方向 のせん断抵抗力により抵抗することで発生しているもの と考えられる. Case1，2では，橋台の回転変形が大きく， 崩壊時に傾斜が生じていたが，Case3，4のように改良体 が連結することにより, 橋台上部で橋台の水平方向の挙 動を引き留め, 更に, 改良体が引き上げられようとする 


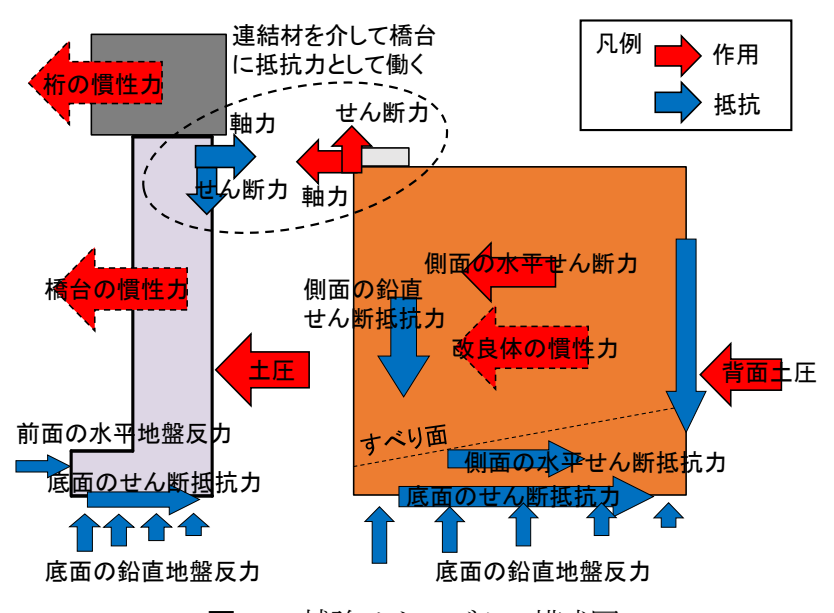

図-24 補強メカニズムの模式図

挙動に対して抵抗することにより，橋台の回転変形が抑 制されるものと推定される.

\section{5. 補強メカニズムの考察}

橋台と改良体を連結することによる補強メカニズムは 改良体の挙動に着目して, 図-24 のように推定される. 改良体には抵抗力として, 水平方向に底面のせん断抵抗 力, すべり面外に生じる傾面の水平せん断抵抗力が働き, 鉛直方向には側面，背面に鉛直方向のせん断抵抗力，底 面の鉛直地盤反力が生じる．作用としては，改良体の慣 性力, 背面土圧が働く. また, 改良体側面に背面盛土に よる水平方向のせん断力が働く. 橋台と改良体を連結す ることにより，両者が一体で挙動することで，上述した 改良体の地盤抵抗力が連結材を介して橋台の抵抗力とし て働き, 橋台の安定性が向上寸るものと考えられる.

\section{6. まとめ}

本研究では, 桁重量が大きい橋台における効果的な補 強工法の開発を目的として, 橋台背面に造成した改良体 と橋台を連結して，一体化することで而震性を向上させ る工法を提案した. 提案工法の補強効果, 補強メカニズ ムを検討するため, 縮尺 $1 / 15$ の模型を用いて重力場で の振動台実験を行い，その結果，今回の実験条件では， 以下の知見が得られた。

(1)橋台と改良体を連結することにより，改良体を連結 しないものに比べて耐震性が向上し, 改良体の長さの 大きいものほど而震性が高くなることを確認した.

(2)無対策，および改良体を設置した場合の崩壊形態は, 橋台の傾斜, 滑動に伴って橋台背面にすべり面が生じ て橋台背面近傍が沈下寸る挙動となった. それに対し て，橋台と改良体を連結寸ることにより，改良体の背 面側にすべり面が発生して，その範囲が沈下し，橋台
は滑動モードにより崩壊に至ることを確認した。

(3)改良体を連結した場合は, 橋台, 改良体, および改 良体に挟まれた背面盛土が一体となって挙動するため, 橋台背面近傍における盛土の沈下は小さくなり, 背面 盛土の沈下抑制効果がある点を確認した.

(4)改良体を連結した場合は，橋台，改良体，および背 面盛土が一体となって挙動するため, 橋台の加速度増 幅は，改良体，盛士のそれと同様の傾向となる.

(5)桁慣性力が大きい場合は，橋台に作用する土圧と慣 性力の位相差が 180 度異なることがあるが，改良体の 連結により, 橋台, 改良体, および背面盛土の位相が 一致し，土圧，慣性力は同位相で作用寸る.

(6)改良体を連結しない場合は，改良体による土圧の低 減効果が働くが，改良体を連結することで，土圧と慣 性力が同位相で作用することに伴い，理論式である修 正物部岡部式と同程度の大きさとなる.

(7)改良体には抵抗力として, 水平方向に底面のせん断 抵抗力, すべり面外に生じる側面の水平せん断抵抗力 が働き，鉛直方向には側面，背面に鉛直方向のせん断 抵抗力，底面の鉛直地盤反力が生じる．作用としては， 改良体の慣性力, 背面土圧が働く.また, 改良体側面 に背面盛土による水平方向のせん断力が働く.

(8)橋台と改良体を連結することにより，橋台，改良体 がが一体で挙動することで, 改良体の地盤抵抗力が連 結材を介して橋台の抵抗力として働き, 橋台の安定性 が向上する.

なお，首都直下地震では，大きな上下方向地震動も作 用寸る可能性があり，上下，水平方向地震動が同時に作 用寸る場合の提案工法の構造全体系に与える影響につい て，検討を深化する必要がある。

謝辞 : 本研究の模型実験においては, 水野弘二氏（東日 本旅客鉄道株式会社），三上和久氏，山口淳氏，大久保 知憲氏（株式会社エムテック）, 山下修史氏（ジェイア 一ル東日本コンサルタンツ株式会社）に多大なご協力を 頂いた．末筆ながら記して謝意を表する.

\section{参考文献}

1) 東日本旅客鉄道株式会社 設備部：新潟県中越地震 鉄道土木構造物災害復旧記録誌, 東日本旅客鉄道, 2006.

2) 垂水尚志, 匹本慶一, 岡田勝也, 福島弘文, 大植英 亮, 川名英二 : 地震時の橋台裏盛土の変状機構と変 状防止対策に関する研究, 鉄道技術研究所速報, No.A-85-33, 1985.

3）阪神・淡路大震災調查報告編集委員会 地盤工学会 土木学会: 阪神淡路大震災調査報告土木構造物の被 害 トンネル・地下構造物・土構造物・基礎構造物, pp.136-137, 1998.

4) 高橋範明, 高崎秀明 : 東北地方太平洋沖地震におけ 
る橋台背面の被害分析, Structural Engineering Data (SED), No.40, pp.68-73, 2012.

5) 福井次郎, 宮本宏一, 染谷克典, 佐伯光昭, 白戸真 大：道路橋橋台およびその基礎の地震被災事例分析， 第 4 回構造物の破壊過程解明に基づく地震防災性向 上に関するシンポジウム論文集，pp.247-252，2003.

6) 福田誠, 木村智博, 鄭光司, 稲場友也, 坂上敏彦, 吉泉直樹：中越・中越沖地震後の橋台等付近で見ら れた段差被害, 地盤工学会誌 土と基礎, Vol.56, No.7, pp.36-39, 2008.

7) 佐々木一夫 : 東北地方太平洋沖地震による直轄道路 橋の被災状況，土木技術資料，Vol.54，No.8，pp.3033, 2012.

8) 国土技術政策総合研究所, 独立行政法人土木研究 所：平成 23 年（2011 年）東北地方太平用沖地震に よる道路橋等の被害調査報告，国総研資料，第 814 号・土研資料，第 4295 号，2014.

9) 岡田勝也, 福島弘文: 地震時における橋台裏盛土の 沈下量評価手法の提案, 土木学会論文集, 第 418 号 /III-13, pp.249-255, 1990.

10) 石田修一, 谷本俊輔, 星隈順一：液状化地盤におけ る橋台の地震時挙動メカニズム, 土木技術資料, Vol.58, No.9, 2016.

11）池本宏文, 鬼頭和也, 高崎秀明, 藤原寅士良, 橘内 真太郎：橋台背面盛土の沈下抑制工法における実験 的検証, 地盤工学特別シンポジウムー東日本大震災 を乗り越えて発表論文集一, pp.431-437, 2014.

12）池本宏文，高崎秀明：桁質量の異なる橋台における 耐震補強効果の実験的検討, 土木学会第 70 回年次 学術講演会, pp.623-624, 2015.

13）猿渡隆史，西岡英俊，山田孝弘：土圧および桁慣性
力の低減による橋台の耐震補強工法に関する振動実 験, 第 49 回地盤工学研究発表会, pp.1435-1436, 2014.

14）日本国有鉄道 構造物設計事務所 : 橋台裏耐震補強工 設計の手引き（案），日本国有鉄道，1981.

15) 光森章, 対馬俊治, 西平宣嗣, 清水竜也, 今村年 成：京王電鉄多摩川橋梁の耐震補強, 基礎工, Vol.44, No.5, pp.38-41, 2016.

16）神田政幸, 須賀基晃, 横山知昭, 舘山勝, 杉本一 郎：橋桁・橋台・盛土一体化による旧式橋りょうの 耐震補強, 鉄道総研報告, Vol.26, No.4, pp.29-34, 2012.

17) 公益社団法人日本道路協会 : 道路橋示方書 - 同解説 IV 下部構造編，公益社団法人日本道路協会, 2012.

18) 財団法人海洋架橋・橋梁調査会 : 既設橋梁の耐震補 強工法事例集, 財団法人海洋架橋 - 橋梁調査会, 2005.

19）運上茂樹，星隈順一，七澤利明，河野哲也，谷本俊 輔：既設橋の液状化被害を防ぐための耐震技術の開 発，土木技術資料，Vol.58，No.1，2016.

20) 香川崇章 : 土構造物の模型振動実験における相似則, 土木学会論文集，第 275 号，pp.69-77， 1978.

21）国土交通省監修，鉄道総合技術研究所編：鉄道構造 物等設計標準 ・同解説 而震設計, 丸善, 2013 .

22) 西岡英俊, 渡辺健治, 篠田昌弘, 澤田亮, 神田政 幸 : 橋台の地震時応答特性に関する実験的検討，第 13 回日本地震工学シンポジウム論文集, pp.13301337, 2010.

\title{
EXPERIMENTAL STUDY OF ASEISMIC RETROFITTING METHOD FOR ABUTMENTS BY LINKING ABUTMENTS TO SOIL-MIXED COLUMN-WALLS
}

\author{
Hirofumi IKEMOTO, Hideaki TAKASAKI, Torajiro FUJIWARA, \\ Taisuke SANAGAWA and Hidetoshi NISHIOKA
}

In this study, methods of aseismic retrofitting were developed for abutments in which soil-mixed column walls are linked to abutments along the sides of tracks, utilizing ground improvement techniques. A shacking table test in gravity field was conducted on a model scale of $1 / 15$ to verify the effect of the proposed method. As a result of the shaking table test, the backfill, which was located between the abutment and the soil-mixed column walls, behaved together with the abutment and the soil-mixed column walls. The abutment collapsed in sliding mode and a failure plane was formation that on the backside of the soilmixed column walls. Thus, it was confirmed by experiment the proposed method improves earthquake resistance since the soil-mixed column walls resisted external force by the subgrade reaction and shear resistance at the bottom and the sides of the soil-mixed column walls during shaking. 